\section{VERTICALIZACIÓN. LA EDIFICACIÓN EN ALTURA EN LA REGIÓN METROPOLITANA DE SANTIAGO (1990-2014)*}

Jorge Eduardo Vergara Vidal ${ }^{\alpha}$

\section{Resumen}

El presente trabajo explora el fenómeno de edificación en altura en las comunas de la Región Metropolitana de Santiago entre los años 1990 a 2014 a partir de un análisis conjunto de los datos de la Encuesta de Edificación (1990-2001) y del Formulario Único de Estadísticas de Edificación (FUEE) (2002-2014), ambos diseñados e implementados por el Instituto Nacional de Estadísticas (INE). Sus resultados permiten identificar un proceso de polarización en las alturas construidas que pueden ser asociadas a formas construidas diferentes, casas y edificios. La proliferación y concentración de estos últimos propone desafíos significativos en el

\section{VERTICALIZATION. HIGH- RISE BUILDINGS IN THE SANTIAGO METROPOLITAN AREA (1990-2014)*}

Jorge Eduardo Vergara Vidal ${ }^{\alpha}$

\section{Abstract}

On the basis of an analysis of data released by the Building Survey (1990-2001) and the Building Statistics Form (FUEE) (2002-2014), both designed and conducted by the National Statistics Institute (INE), this paper explores the phenomenon of high-rise in different municipalities of the Metropolitan Region over the period 1990 to 2014. The results enable the identification of a process of polarization focused on high-rise constructions, which can be regarded either as houses or buildings. The proliferation and concentration of the latter category poses a significant challenge to 
gobierno a las comunas pericentrales de la región e inspira considerar la forma construida como problema urbano diferente al de la vivienda y de al residencialidad.

\section{PALABRAS CLAVE: EDIFICACIÓN EN ALTURA, FORMA CONSTRUIDA, VERTICALIZACIÓN, GOBERNANZA.}

Recibido: 14/03/2016

Aceptado: 10/03/2017

* Investigación doctoral "El objeto técnico como logro asociativo. El ascensor NEXIEZ-MR de Mitsubishi en Santiago de Chile", financiado por Beca de Doctorado Nacional, CONICYT.

$\alpha \quad$ Chile. Departamento de Sociología, Universidad de Chile. Correo electrónico: jvergaravida@@uchile.cl peri-central municipalities and invites us to think of the built form as an urban issue different than that of housing.

KEYWORDS: HIGH-RISE BUILDINGS, BUILT FORM, VERTICALIZATION, GOVERNANCE.

Received: 14/03/2016

Accepted: 10/03/2017

* CONICYT-funded doctoral research "The technical object as associative achievement. The Mitsubishi NEXIEZ-MHR lift in Santiago, Chile".

$\alpha \quad$ Chile. Department of Sociology, University of Chile. Email: jvergaravidal@uchile.cl 


\section{Introducción}

En 1896, el arquitecto Luis Sullivan resume en su "The tall office building artistically considered" las condiciones sociotécnicas que permitieron la "invención" del edificio de altura: la estructura de acero, el hormigón armado y los ascensores (Sullivan, 1896; Abbott, 2000; Koolhaas, 2004, 2014). La conjunción de estos tres elementos permitieron a los arquitectos, según Sullivan, responder a las necesidades planteadas por sus sociedades respecto a una utilización rentable comercialmente de los caros suelos centrales de las ciudades norteamericanas mediante una forma construida nueva y adecuada a las necesidades administrativas del capitalismo moderno: el edificio de oficinas en altura.

Como explica el mismo Sullivan, las condiciones que permitieron tanto la concreción como la proliferación de esta particular forma construida son relativamente sencillas:

"las oficinas son necesarias para las transacciones de negocios; la invención y el perfeccionamiento de los elevadores rápidos hacen del viaje vertical, una vez era tedioso y molesto, algo fácil y cómodo; el desarrollo de las manufacturas de acero ha abierto el camino a la construcción de edificios seguros, rígidos, y económicos de gran altura; el continuo crecimiento de la población de las grandes ciudades, y la consecuente congestión de los centros y aumento del valor de la tierra, estimulan un mayor número de pisos; estos, felizmente apilados unos sobre otros, inciden sobre el

\section{Introduction}

In "The Tall Office Building Artistically Considered" (1986), architect Louis Sullivan describes the socio-technical conditions that enabled the "invention" of high-rise buildings: steel structures, reinforced concrete and elevators (Sullivan, 1896; Abbott, 2000; Koolhaas, 2004, 2014). The combination of these elements enabled architects to meet the needs of societies, which demanded the cost-effective use of expensive land located in the central areas of North American cities through the elaboration of new built forms suitable to the administrative needs of modern capitalism: high-rise office buildings.

According to the author, the conditions that enabled the materialization and proliferation of these particular built forms are relatively simple:

"offices are essential for businesses; the invention and improvement of fast elevators turned vertical movement, a once tedious and unpleasant activity, into an easy and comfortable experience; the development of the steel industry has enabled the construction of safe, solid and low-cost highrise buildings; the continuous growth of the population in large cities and the consequent saturation of central areas and increase in the price of land have favored the construction of taller buildings, whose stories, comfortably 
valor de la tierra - y así sucesivamente, por acción y reacción, e interacción. Y así ha surgido esa forma de construcción elevada que llamamos el "moderno edificio de oficinas". Ha surgido en repuesta a una necesidad, pues en ella un nuevo agrupamiento de condiciones sociales ha encontrado una habitación y un nombre" (Sullivan, 1896, p. 403).

Los elementos y motivaciones, identificados por Sullivan, no solo estaban presentes en las ciudades como Chicago y Nueva York, sino también en ciudades periféricas como Santiago de Chile. Tanto la tecnología que hacían posible esta forma construida, como el interés de quienes podían financiarlas, se conjugaron con quienes podían construirlas hacia fines de las primera década del siglo XX y las construcciones basadas en cemento hormigón, acero y elevadores comenzaron a ser construidos en las manzanas centrales de la ciudad por mandantes como el Diario Ilustrado, el Ministerio de Hacienda, los Bancos y las Cajas de Seguros.

Para fines de las década de 1920, las edificaciones de hormigón comenzaron a ganar altura sobre los ocho pisos y a ser llamados rascacielos en revistas especializadas, como "Arquitectura y Arte Decorativo" que realizó una serie de artículos sobre el fenómeno, en uno de los cuales indicaba: "Construir. Los rascacielos perfilan sus siluetas airosas y esbeltas sobre la masa uniforme de la ciudad antigua"1. Por cierto no solo era la forma la que

1 En: Arquitectura y Arte Decorativo (11), 1930, p. 469. placed one on top of the other, affect the price of land within the context of an action, reaction and interaction process. These elements have given rise to this type of highrise construction, the so-called "modern office building." Such a structure emerged as a response to specific needs since it provides a home and identity to a new group of social conditions" (Sullivan, 1896, p. 403).

The elements and motivations identified by Sullivan were not only found in cities such as Chicago and New York, but also in peripheral cities such as Santiago, Chile. By the end of the first decade of the XX century, both the technology that enabled the development of these built forms and the interest of those who were able to finance the construction of these structures met those with the means to build them. This led to the emergence of the first elevator-equipped constructions made of concrete and steel in the central area of the city; these were built at the request of entities such as Diario Ilustrado, the Ministry of Finance, Banks and Security Funds.

By the end of the 1920s, concrete buildings were as tall as eight stories, being regarded by specialized journals, such as Arquitectura y Arte Decorativo, as skyscrapers. This publication issued a series of articles about the phenomenon, such as a feature entitled "Building. Skyscrapers Show their Gracious and Slim Lines over the 
claramente se distinguía como novedosa respecto a la "ciudad anterior", de baja altura y en general de adobe y madera. La forma traía consigo nuevos mercados para productos como el acero (utilizado en perfiles, ventanas, elevadores), el cemento, los recubrimientos de pisos y fachadas, los artefactos de oficina y hogar, entre otros. Las revistas de arquitectura eran espacio de anuncio de las nuevas materialidades y tecnologías, como las ventanas de acero y las estufas a gas, que indicaban cambios radicales en la gestión de la espacialidad de los hábitats urbanos (Aguirre, 2012; Sahady, 2014; Jara, 2015).

Casi la totalidad de ese proceso edificatorio se desarrolló en las manzanas centrales de la ciudad que conjuntaban sus núcleos comercial, financiero y gubernamental. Esta primera edificación en altura incluye la obra de Manuel Cifuentes Gómez (Intendencia de Santiago); Alberto Sieguel (Edificio Compañía Sudamericana, Banco de Chile, Hotel Crillón, Teatro Central); Alberto Cruz Montt (Palacio Aristía), Guillermo Schneider (edificios Turri); Larraín Bravo (Iglesia de los Sacramentinos); Josué Smith Solar y Josué Smith Miller (edificios Ministerio de Hacienda y Hotel Carrera) que entre otros arquitectos fueron los autores de un perfil de altura que bordeó los 12 pisos en un radio no mayor de 10 manzanas (Sahady, 2014).
Homogenous Old City". In this case the form of these buildings did not only describe the emergence of new structures within the "old city" -which was mainly composed of small adobe and wood buildings-, but it also referred to the emergence of new markets for products such as steel (used to elaborate steel sections, windows and elevators), concrete, façade systems, floor covering materials and office and home items, among others. Architecture journals disseminated the arrival of new materials and technologies such as steel windows and gas stoves, which implied dramatic changes in the spatial management of urban habitats (Aguirre, 2012; Sahady, 2014; Jara, 2015).

This building process was primarily focused on the central area of the city, in proximity to the main commercial, financial and governmental activities. The first high-rise buildings included those designed by Manuel Cifuentes Gómez (Regional Government Office); Alberto Sieguel (Compañia Sudamericana Building, Banco de Chile, Hotel Crillón, Teatro Central); Alberto Cruz Montt (Palacio Ariztía), Guillermo Schneider (Turri Building); Larrain Bravo (Sacramentinos); Josué Smith Solar and José Smith Miller (Ministry of Finance and Carrera Hotel), among other architects who envisioned

Arquitectura y Arte Decorativo (11), 1930, p. 469. 
Esos edificios no solo aportaron a la ciudad una nueva piel y un nuevo perfil, también significaron la entrada en ella de los arquitectos, como los nuevos artífices de lo urbano, no solo desde la obra edificada, sino también desde su papel en el diseño de normativa urbana desde la DOM de Santiago. Las estadísticas de edificación nacionales comienzan en esta época. Sus primeras recolecciones las realiza el mismo Municipio de Santiago en 1928 y provienen de los permisos de edificación otorgados ese año. Su intención era verificar y fortalecer la aplicación de las ordenanzas municipales, las que principalmente estaban orientadas a resguardar las condiciones de salubridad de calles y edificaciones según los preceptos del urbanismo vigente en la época (Asociación de Arquitectos, 1934).

En las décadas siguientes, la construcción de edificios de altura se extendió a otras comunas como Providencia y Las Condes, pero a pesar de su incidencia en el perfil urbano, ello no trajo consigo un reemplazo masivo de casas por edificios al nivel de las últimas dos décadas. Son muchos y variados los casos que considerar entre los edificios de altura construidos con posterioridad a la década de 1940, en su gran mayoría con fines administrativos y comerciales, pero los hay también de uso residencial como las remodelaciones San Borja y República, las torres de Apoquindo y de Carlos Antúnez, las villas Frei y Olímpica, que superan todos los 15 pisos de altura, construidos en general con posterioridad a 1960. the construction of buildings as tall as 12 stories within a ten-block radius (Sahady, 2014).

These buildings provided the city with a new appearance and enabled the emergence of architects as urban artists -not only in terms of their built construction but also in terms of their role in the design of new urban regulations. The first building statistics were introduced in 1928 by the Municipality of Santiago through the collection of building permits. The goal of this initiative was to corroborate and strengthen the implementation of municipal ordinances, which were mainly oriented towards maintaining hygiene in streets and buildings according to the then-current urban standards (Asociación de Arquitectos, 1934).

Over the following decades the construction of high-rise buildings was extended to other municipalities such as Providencia and Las Condes; however, despite their impact on the urban landscape, these structures did not replace houses with buildings until the last two decades. There are many different cases of highrise buildings built after the 1940s and despite most of them were intended for administrative and commercial purposes, a handful of them were designed to meet residential needs, some examples of the latter are the República and San Borja developments, the Apoquindo and Carlos Antúnez towers and the Olympic and Frei 
Sin embargo, y a pesar de su evidente incidencia urbana, es difícil establecer con certeza cuántos edificios fueron construidos en aquella época y/o analizar el fenómeno de su proliferación en la zona urbana de Santiago. La razón de esto radica en el núcleo de la contabilidad urbana consolidado a partir del Censo de 1958 que se basa en la unidad de vivienda, que corresponde al uso y no a la forma de ocupación espacial. Sumado a eso, solo a fines de 1980 fue posible contar con un instrumento consolidado que permitiese sistematizar la información de los permisos de construcción emitidos por las municipalidades en todo el país.

Este instrumento, denominado Encuesta de Edificación, fue elaborado por el Departamento de Estadísticas de INE y que correspondía a un formulario que debía ser llenado por los arquitectos encargados de las obras como parte de los trámites del permiso de edificación y de la recepción final de las obras por parte de los municipios. La Encuesta de Edificación, tuvo vigencia entre 1989 a 2001. El nuevo instrumento, el Formulario Único de Estadísticas de Edificación (FUEE), vigente desde 2002 en adelante, contó con la participación del MINVU y la Cámara Chilena de la Construcción, dos actores centrales en lo que tiene que ver con la edificación en el país y que no modificaron el núcleo epistémico del instrumento sino que más bien ampliaron los rangos de medición de las variables ya presentes (INE, 2003a; 2003b; 2004; 2006; 2007). development -all of them taller than 15 stories and built after the 1960s.

However, and despite their effect on the urban system, it is difficult to make an estimate of the number of buildings built over the period under review and/or analyze their proliferation in the urban area of Santiago. The reason is that the 1958 Census recorded only the general use and not the spatial use of housing units. Likewise, it was only at the end of the 1980s that a consolidated instrument was created to systematize information about the building permits issued by municipalities throughout the country.

Such an instrument, known as the Building Survey, was elaborated by the Statistics Department at the National Statistics Institute (INE) and consisted of a form that should be filled by chief architects and submitted to municipalities as part of the building permit issuing process and as a final receipt of projects. This Building Survey was used during the period 1989 to 2001. The new instrument, designed by MINVU and the Chilean Chamber of Construction and known as Building Statistics Form (FUEE), was introduced in 2002 and is still being used today. The two entities in charge of the development of this initiative -regarded as key players within the context of local construction-did not modify the core elements of the previous instrument but 
Como se señaló anteriormente, estos instrumentos no está diseñados para medir forma construida, sino el número de viviendas y superficies de las edificaciones y sus habilitaciones, por tanto tienen limitaciones significativas. Solo se considera, por ejemplo, hasta el noveno piso de cualquier edificación, siendo imposible diferenciar si esta tiene 10 o 20 pisos. A pesar de ello, ambos instrumentos presentan una continuidad metodológica, lo que permite seguir la evolución de algunas variables entre 1990 y 2014 y sacar algunas conclusiones sobre la forma construida en la ciudad.

\section{Metodología}

La metodología utilizada para analizar el proceso edificatorio en la ciudad de Santiago se basó en el análisis estadístico de una base de datos que integró la información de la Encuesta de Edificación (1990-2001) y del Formulario Único de Estadísticas de Edificación (2002-2014), ambos instrumentos del Instituto Nacional de Estadísticas (INE), en lo que refiere al de número de viviendas, las superficies construidas, las materialidades predominantes y el número de pisos de edificaciones de obra nueva, con permiso de edificación y recepción, en comunas de la Región Metropolitana de Santiago.

La consolidación de datos permitió analizar el comportamiento de las variables señaladas en un expanded the measurement ranges of already existent variables (INE, 2003a; 2003b; 2004; 2006; 2007).

As mentioned above, these limited instruments were not designed to measure built forms but the number of dwellings, built floor areas and rooms. For instance, as they only measure variables for the first nine stories, this makes it impossible to distinguish a 10-story building from a 20-story building. However, both instruments show a methodological continuity, making it possible to monitor the evolution of some variables over the period 1990 to 2014 and draw some conclusions about the built form of the city.

\section{Methodology}

The methodology used in this research was based on the statistical analysis of data released by the Building Survey (1990-2001) and the Building Statistics Form (2002-2014). Both instruments were developed by the National Statistics Institute (INE) to monitor the number of dwellings, built floor areas, materials used and number of stories of new buildings -both with official building permits and proper submission to relevant authorities - within the Metropolitan Region of Santiago. 
rango de tiempo de 25 años (1990 y 2014) y generar una imagen del proceso edificatorio de la Región en tal periodo, aunque con limitaciones, como la de no poder determinar el número de edificaciones y/o tener información específica sobre edificaciones sobre los nueve pisos. El análisis estadístico, por su parte, permitió identificar las principales características de este proceso.

La primera de estas características tiene relación con las variaciones de intensidad en el proceso edificatorio en el periodo de tiempo observado que no solo presenta altos y bajos adjudicables a los ciclos económicos, sino que también evidencia que estos movimientos son principalmente encarnados por edificaciones de baja y mayor altura. Estas últimas cobran especial protagonismo en la última década observada y logran capturar la imaginería del proceso, polarizándolo.

Una segunda característica que es posible verificar a partir del análisis del destino de las superficies edificadas es que el proceso edificatorio es alentado por un uso residencial (viviendas). Si bien esto es un uso convencional para las edificaciones de baja altura, es novedosa la masividad del sentido residencial de las edificaciones de mayor altura, sobre todo por el tipo de movilización de recursos humanos y técnico que requiere la habilitación residencial de esa forma arquitectónica y su mantenimiento (Allen, 2013; Ng, 2010).
Data consolidation enabled the analysis of the above variables over a period of 25 years (1990 to 2014) and the description of the building process that took place within the Region; however, there were some limitations due to the lack of information about structures taller than nine stories and the total number of buildings. On the other hand, the statistical analysis identified the main characteristics of this process.

The first of these characteristics is related to the variations in the intensity of the building process within the period under review, which does not only show a series of oscillations associated with economic cycles, but also demonstrates that these fluctuations are represented by the height of buildings. The latter is particularly observed during the last decade of the period analyzed as these constructions represent the spirit of the process.

The second characteristic is associated with the promotion of residential use. While this use is common in the case of low-rise constructions, it is new in terms of the widespread increase in the number of residential high-rise buildings, especially when it comes to considering the mobilization of human and technical resources for the construction and maintenance of this type of buildings (Allen, 2013; Ng, 2010).

The above is associated with a third characteristic, which identifies the location of 
Esto se vincula a una tercera característica posible de notar en el proceso edificatorio que tiene relación con la ubicación de los edificios residenciales de altura en las comunas de pericéntricas y de mayores ingresos de la región, y de las viviendas bajas en el resto de las comunas. Esto conlleva a una polarización urbana en torno a la forma arquitectónica, pero no es una expresión directa de la segmentación económica de la ciudad. En lo que sigue se revisan con más detalles las tres características mencionadas, así como sus posibles implicancias.

\section{La tendencia a la altura en el proceso de edificación en la Región Metropolitana entre 1990 y 2014}

Al respecto los datos de la base consolidada señalan que en términos generales, entre los años 1990 y 2014, se edificaron 1.241 .014 viviendas en obras nuevas en las comunas de la Región Metropolitana, construyendo en ello una superficie de 91.676.930 de metros cuadrados. Estos resultados no se distribuyen homogéneamente entre los años del periodo. En los primeros años de la década del 90, el desempeño comparado del número de viviendas con los metros de superficie edificados indica la edificación de vivienda de menor superficie, una tendencia persistente pero que se ha visto high-rise residential buildings in peri-central and more affluent municipalities and low-rise structures in other areas. This generates urban polarization; however, such a phenomenon is not a direct consequence of economic segmentation. The following section analyzes these three characteristics and their potential implications.

\section{A Trend towards the Construction of High-Rise Buildings in the Metropolitan Region over the Period 1990 to 2014}

In general terms, 1,241,014 new buildings were built in the Metropolitan Region between 1990 and 2014, covering a built area of 91,676,930 square meters; however, these figures are not homogeneously distributed over the period under review. For the period covering the early 1990s, the comparison between the number of dwellings and built floor areas suggests the construction of smaller housing units; this is a continuing trend that has been partially modified over the last 5 years (see Figure 1). The latter also shows the massive construction of social housing during the early 1990s and an increase in the 
levemente modificada en los últimos cinco años (figura 1). Esto puede indicar una predominancia de edificación de vivienda social en los primeros cinco años de la década de los 90 por sobre cualquier otro tipo de vivienda y, en contrario una mayor participación de viviendas de sectores más adinerados en los últimos cinco años del periodo. Otro aspecto a notar es la baja en la edificación de viviendas en la región entre los años 1998 y 2000 y entre 2007 y 2010, lo que coincide con crisis económicas y socio ambientales como el terremoto de 2010.

Como se señaló, las encuestas consultadas contienen el dato del número de pisos de la edificación que contiene a la vivienda, a partir de eso es posible identificar la distribución de viviendas según el tipo de edificaciones basados en el número de pisos de estas. La figura 2 nos muestra la evolución del número de viviendas en edificaciones de obra nueva en el periodo observado según su ubicación en edificaciones de 1 a 9 pisos o más. A partir de ello es posible apreciar tanto la alta preponderancia de las viviendas en edificaciones de 1 a 2 pisos, que en el segundo caso persisten en todo el periodo observado, mientras que en el primer caso tiende a decaer a partir de 1993; como el literal despegue de las viviendas en edificaciones de nueve pisos y más a partir del año 2002, interrumpida por una abrupta baja en el año 2010, donde ocurre un terremoto que tuvo como emblema de sus daños a edificios en altura. Esto permite apreciar con claridad un proceso de edificación que progresivamente distribuye las viviendas entre formas construidas polares, entre casas y edificios de altura. building of dwellings aimed at wealthier groups over the last five years of the period under review. Another point to consider is a drop in building rates over the periods 1998 to 2000 and 2007 to 2010, coinciding with economic and socio-environmental crises, such as the 2010 earthquake.

As mentioned above, the analyzed data contained the number of stories of buildings. This contributed to identify the distribution of dwellings according to the type and height of buildings. Figure 2 shows the evolution of the number of new buildings ranging from 1 to 9 or more stories during the period under review. This reveals the predominance of dwellings consisting of 1 or 2 stories. In the latter case, there is a constant presence of this type of construction during the reviewed period; as for the former case, there is a decreasing trend in the number of built units since 1993. Likewise, the year 2002 marked the rise in the construction of buildings taller than nine stories; this phenomenon was interrupted in 2010 as the consequence of the earthquake that particularly affected high-rise buildings. This clearly shows a building process that divides built forms into houses and high-rise buildings. 
FIGURA 1. NÚMERO Y SUPERFICIE VIVIENDAS EN EDIFICACIONES DE OBRA NUEVA EN COMUNAS DE LA REGIÓN METROPOLITANA 1990-2014

FIGURE 1. NUMBER AND BUILT FLOOR AREAS OF DWELLINGS OF NEW BUILDINGS WITHIN METROPOLITAN REGION, 1990-2014.

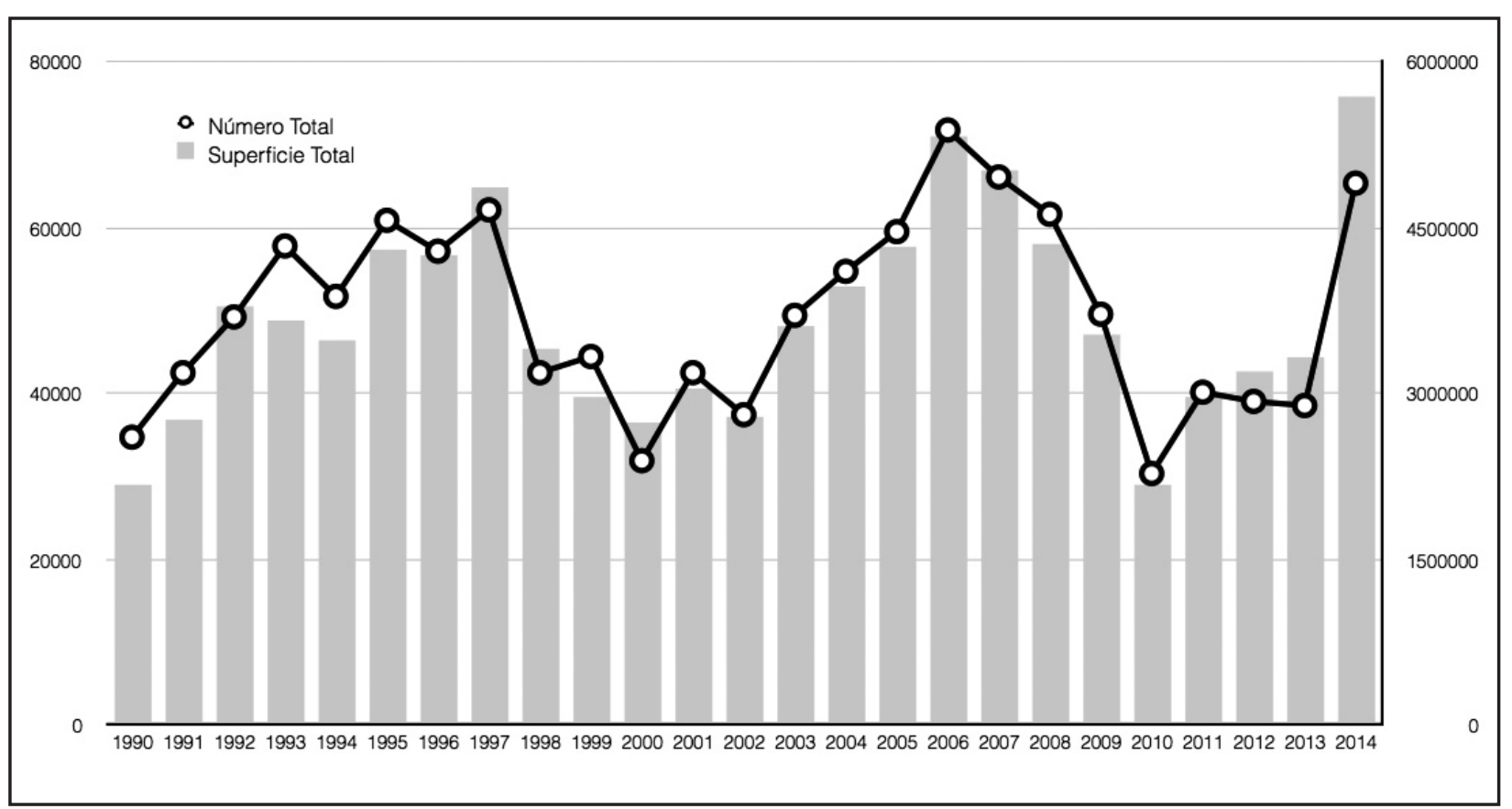

Fuente: Elaboración propia según estadísticas de edificación INE.

Source: Elaborated by the author according to building statistics released by INE. 
FIGURA 2. NÚMERO DE VIVIENDAS EN EDIFICACIONES DE OBRA NUEVA EN COMUNAS DE LA REGIÓN METROPOLITANA, SEGÚN NÚMERO DE PISOS 1990-2014

FIGURE 2. NUMBER OF DWELLINGS BUILT IN NEW BUILDINGS WITHIN THE METROPOLITAN REGION, DISTRIBUTED PER HEIGHT 1990-2014.

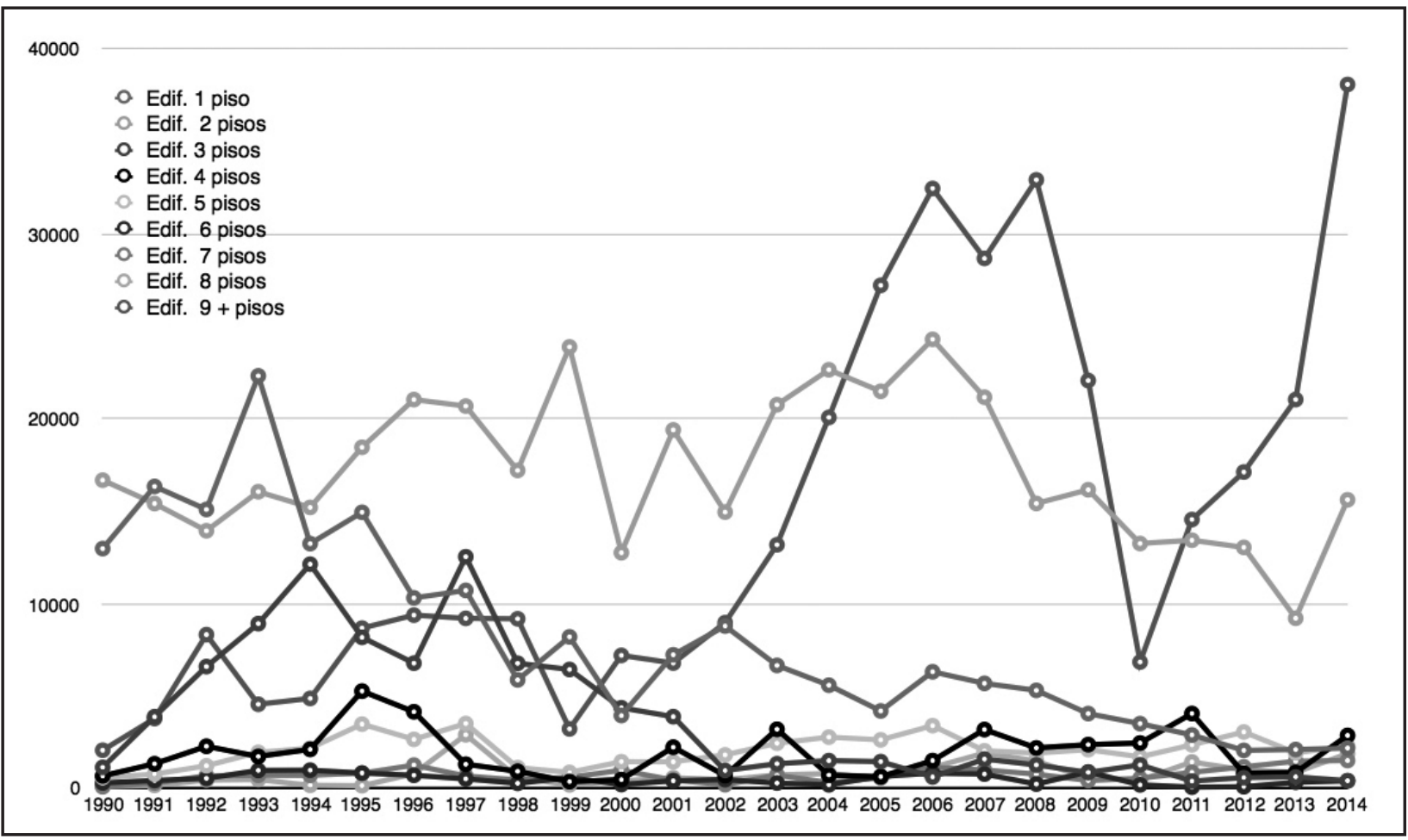

Fuente: elaboración propia según estadísticas de edificación de INE.

Source: Elaborated by the author according to building statistics released by INE. 
Respecto a las viviendas ubicadas en alturas intermedias, es significativo lo que sucede con aquellas ubicadas en edificaciones de tres pisos, que tienen una participación importante en la década de los 90 y cuya edificación pierde intensidad posteriormente. Tanto esta altura como la de 4 y 5 pisos por lo general están asociadas a la forma de vivienda colectiva identificada como blocks, utilizadas masivamente para acoger viviendas sociales en la década de los 90 y que pierden notablemente participación en el proceso a partir del 2002. Al decaer la ubicación de viviendas en estas edificaciones intermedias su producción se distribuye polarmente entre las edificaciones de menor y mayor altura. Esto comienza alrededor del año 2001 y se consolida en el 2005, articulando un fenómeno que polariza tanto las alturas de las edificaciones residenciales como sus formas.

Por su parte, la evolución de la distribución de superficies en las edificaciones, considerando el número de pisos de estas, nos muestra algunas variaciones que son útiles para establecer las particularidades del proceso (figura 3). Uno de esas es la diferencia de la evolución de la línea de edificaciones de un piso con la de edificaciones de nueve y más pisos en el periodo 92-93, con lo que se puede apreciar en el mismo periodo en la figura 2. El hecho de que la superficie de nueve pisos y más sobrepase la superficie de un piso, mientras en números se da todo lo contrario, nos informa sobre el destino de la unidad residencial edificada:
As for dwellings built in intermediate buildings, importance should be given to the situation of 3-storey buildings and 4-5-storey buildings. These structures are commonly associated with the typology of housing blocks, a form of collective housing intended to house a large number of social dwellings. The production of these types of buildings proliferated during the 1990s, but has been declining since 2002. This downward trend has led to an increase in the construction of low and high-rise buildings. Such a phenomenon began in 2001 and became consolidated in 2005, polarizing the heights and forms of residential buildings.

On the other hand, the evolution of the distribution of built floor areas -which is based on the number of stories- shows some variables that describe the characteristics of this process (see Figure 3). One of these features is the difference between the evolution of 1-storey buildings and structures taller than nine stories over the period 1992 to 1993. Despite figures showing the opposite, the fact that the built floor areas of new buildings taller than nine stories are greater than those of one-storey buildings reveals the purpose of these residential units: the presence of few dwellings with large built floor areas is hardly associated with low-or mediumcost housing. This trend, which was based on the construction of dwellings with greater built floor areas that dominated the following decade, 
si son pocas viviendas, pero amplias en superficie, es difícil asociarlas a viviendas de bajo o mediano precio. Esa tendencia de la edificación en altura en la década de 1990, asociada a la mayor superficie de las viviendas se ve revertida en la década siguiente, que es justamente la década de proliferación de esa forma construida y de las unidades de vivienda edificadas en ella, lo que indica que ese proceso de proliferación se hace a coste de la superficie asociada a las viviendas. Si su superficie es menor que en la década anterior, se podría suponer que su coste y quienes acceden a vivir en ellas tiene ingresos menores que los del periodo anterior, ya sea porque la cantidad de ocupantes por unidad son menores y/o por que presentan ingresos menores que los ocupantes de unidades de vivienda de mayor superficie. Tal parece ser el motor del proceso edificatorio posterior al año 2000, sobre todo si se comparan estas cifras con las cifras censales de comunas como Santiago que duplicaron su población junto con la construcción de edificios residenciales, pero cabe dudar si el proceso es socio económicamente similar en comunas de alta renta como Ñuñoa, Las Condes u otras.

Si consideramos solo las viviendas ubicadas en edificaciones entre los 4 a 8 pisos (figura 4) podemos apreciar que las tendencias altas y bajas en estas categorías no logran consolidarse, salvo las edificaciones de seis pisos que mantiene una tendencia a la baja. Esto permite pensar que no se trata de alturas que logren predominar como opción para la ubicación de viviendas. was reversed during the following decade as the consequence of the proliferation of new built form; such a phenomenon indicates that massive construction was made at the expense of the size of built floor areas. Therefore, if the floor areas of current dwellings is smaller than that of the previous decade, it could be assumed that their cost and the economic resources of occupants are less than those of the previous period; the latter may be due to the fewer number of occupants per housing unit and/or they earn less income than the occupants of larger dwellings. This seems to be the main driving force behind the post-2000 building process, especially when it comes to comparing these figures with Census data for municipalities such as Santiago -which doubled its population as the result of the construction of residential buildings. However, there are doubts as to whether this process has the same socioeconomic characteristics in high-income municipalities such as Nuñoa or Las Condes, among others.

If we only consider the dwellings built in 4-8-story buildings (see Figure 4), it is possible to observe unstable increasing and decreasing trends, the exception being the downward trend shown by six-story buildings. This suggests that the heights of constructions are not a determining factor when it comes to establishing the physical location of dwellings. 
FIGURA 3. SUPERFICIE DE VIVIENDAS EN EDIFICACIONES DE OBRA NUEVA EN COMUNAS DE LA REGIÓN METROPOLITANA, SEGÚN NÚMERO DE PISOS 1990-2014

FIGURE 3. BUILT FLOOR AREAS OF DWELLINGS IN NEW BUILDINGS WITHIN THE METROPOLITAN REGION DISTRIBUTED PER HEIGHT, 1990-2014.

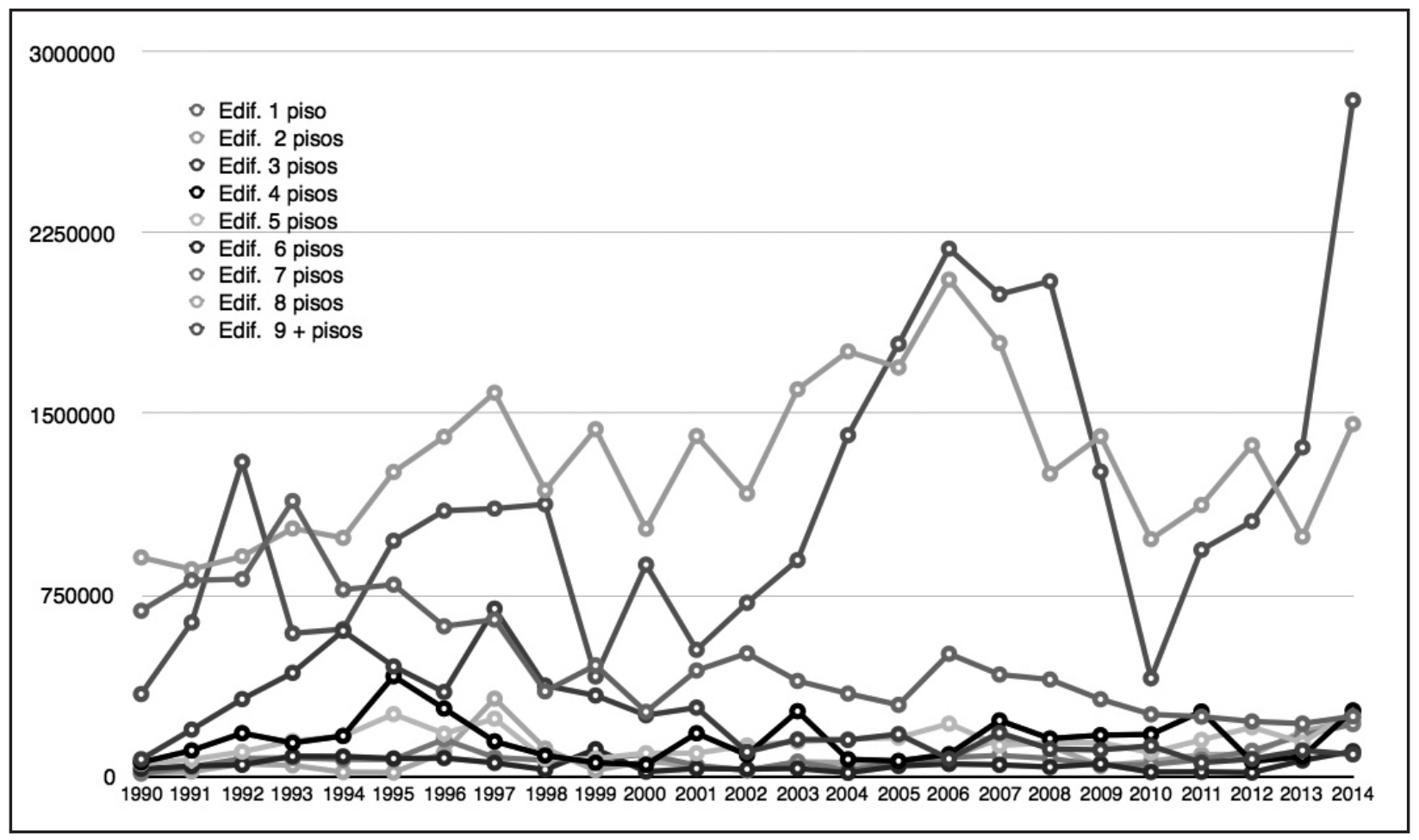

Fuente: elaboración propia según estadísticas de edificación de INE.

Source: Elaborated by the author according to building statistics released by INE. 


\section{La tendencia polar de lo residencial}

Sullivan (1896) vincula la forma construida a su uso, y en el caso de los altos edificios a los que se refiere este uso es casi exclusivamente comercial. Ello tenía sus razones, la más potente de todas era el origen del financiamiento y, claro, Sullivan sabía que solo ciertas entidades comerciales podían costear la innovación arquitectónica que su generación estaba desarrollando. En el caso chileno, siguiendo la misma tendencia, las primeras edificaciones en altura fueron financiadas principal y mayoritariamente por Bancos, Cajas y Aseguradoras, y muy pocas de ellas fueron destinadas a fines residenciales. Sin embargo, los datos analizados evidencian que este aspecto se ha invertido y en los últimos 25 años la mayor cantidad de superficie edificada en alturas por sobre los nueve pisos corresponde a usos residenciales, siendo esta la forma elegida para densificar las comunas centrales de la ciudad.

El efecto urbano de lo señalado es la consolidación masiva de dos formas construidas polares: casas y edificios. Como es posible apreciar en la tabla 1 y en la figura 5, las superficies de edificaciones de 1 y 2 pisos asociadas al uso residencial capturan el $48,9 \%$ de la superficie de obra nueva edificada en la región en los últimos 25 años y el 67,5\% de las edificaciones de uso no residencial (tabla 1 ). Por su parte las superficies de edificaciones de nueve

\section{Opposite Residential Trends}

Sullivan (1896) relates built form to use, the latter concept being associated with high-rise buildings and commercial activities. Such a relationship was made on financial grounds as Sullivan knew that only a handful of commercial entities were able to fund the then-emerging architectural innovation. In Chile, the first high-rise buildings were mainly financed by Banks, Security Funds and Insurance Companies; likewise, a few of these constructions were designed for residential purposes. However, the analyzed data show a reverse trend over the last 25 years which have witnessed an increase in the construction of residential high-rise buildings taller than nine stories, this being the preferred option to increase density in central municipalities.

The urban consequence of this initiative is the massive consolidation of two opposite built forms: houses and buildings. As described by Table 1 and Figure 5, the built floor areas of 1-2-story residential structures account for 48.9 percent of new buildings and 67.5 percent of non-residential constructions built over the last 25 years (see Table 1). On the other hand, the built floor areas of residential buildings taller than nine stories account for 31 percent of built structures and 13 percent of non-residential constructions built over the observed period. Intermediate buildings consisting of 3 to 5 stories only account for 
FIGURA 4. NÚMERO DE VIVIENDAS EN EDIFICACIONES DE OBRA NUEVA EN COMUNAS DE LA REGIÓN METROPOLITANA, SEGÚN NÚMERO DE PISOS 4 A 8, 1990-2014

FIGURE 4. NUMBER OF DWELLINGS BUILT IN NEW 4-8-STORY BUILDINGS WITHIN THE METROPOLITAN REGION, DISTRIBUTED PER HEIGHT, 1990-2014.

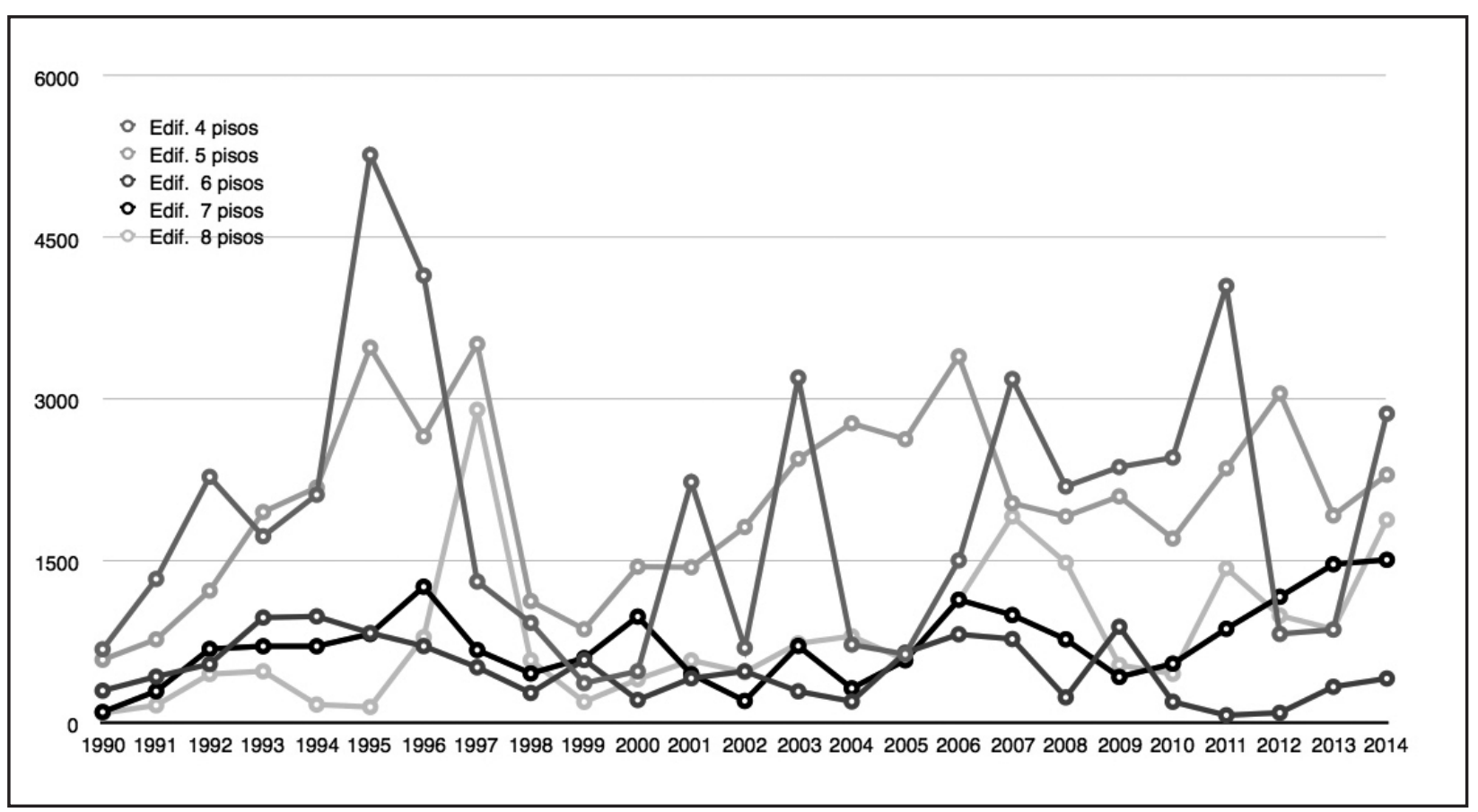

Fuente: elaboración propia según estadísticas de edificación de INE.

Source: Elaborated by the author according to building statistics released by INE. 
TABLA 1. SUPERFICIE DE VIVIENDAS Y DE NÚMERO VIVIENDAS EN EDIFICACIONES DE OBRA NUEVA SEGÚN NÚMERO DE PISOS ENTRE 1990 A 2014 EN LA REGIÓN METROPOLITANA

\begin{tabular}{|c|c|c|c|c|}
\hline Pisos & Superficie Viviendas & $\%$ & Superficie No Viviendas & $\%$ \\
\hline 1 piso & 12170881 & 13,3 & 20638020 & 41,0 \\
\hline 2 pisos & 32621271 & 35,6 & 13363726 & 26,5 \\
\hline 3 pisos & 5847790 & 6,4 & 4582802 & 9,1 \\
\hline 4 pisos & 3839217 & 4,2 & 2252839 & 4,5 \\
\hline 5 pisos & 3596570 & 3,9 & 1065372 & 2,1 \\
\hline 6 pisos & 1199001 & 1,3 & 976183 & 1,9 \\
\hline 7 pisos & 1893260 & 2,1 & 475010 & 0,9 \\
\hline 8 pisos & 2072700 & 2,3 & 467616 & 0,9 \\
\hline $9 y+$ pisos & 28436240 & 31,0 & 6541558 & 13,0 \\
\hline Total & 91676930 & 100,0 & 50363126 & 100,0 \\
\hline
\end{tabular}

Fuente: Elaboración propia según estadísticas de edificación de INE.

TABLE 1. BUILT FLOOR AREAS AND NUMBER OF DWELLINGS WITHIN THE METROPOLITAN REGION, DISTRIBUTED PER HEIGHT, 1990-2014

\begin{tabular}{|lrrrr|}
\hline Stories & $\begin{array}{c}\text { Built Area } \\
\text { Residential Purposes }\end{array}$ & Percentage & $\begin{array}{r}\text { Built Area } \\
\text { Non-Residential Purposes }\end{array}$ & Percentage \\
\hline 1 story & 12170881 & 13.3 & 20638020 & 13,0 \\
\hline 2 stories & 32621271 & 35.6 & 13363726 & 26,5 \\
\hline stories & 5847790 & 6.4 & 4582802 & 9,1 \\
\hline 4 stories & 3839217 & 4.2 & 1065372 & 4.5 \\
\hline 5 stories & 3596570 & 3.9 & 976183 & 2.1 \\
\hline 6 stories & 1199001 & 1.3 & 475010 & 1.9 \\
\hline stories & 1893260 & 2.1 & 467616 & 0.9 \\
\hline stories & 2072700 & 2.3 & 6541558 & 0.9 \\
\hline stories and taller & 28436240 & 31.0 & 50363126 & 13.0 \\
\hline Total & 91676930 & 100.0 & 100.0 \\
\hline
\end{tabular}

Source: Elaborated by the author according to building statistics released by INE. 
FIGURA 5. SUPERFICIE DE VIVIENDAS Y DE NÚMERO DE VIVIENDAS EN EDIFICACIONES DE OBRA NUEVA SEGÚN NÚMERO DE PISOS ENTRE 1990-2014 EN LA REGIÓN METROPOLITANA

FIGURE 5. BUILT FLOOR AREAS AND NUMBER OF DWELLINGS OF NEW BUILDINGS WITHIN THE METROPOLITAN REGION, DISTRIBUTED PER HEIGHT, 1990-2014

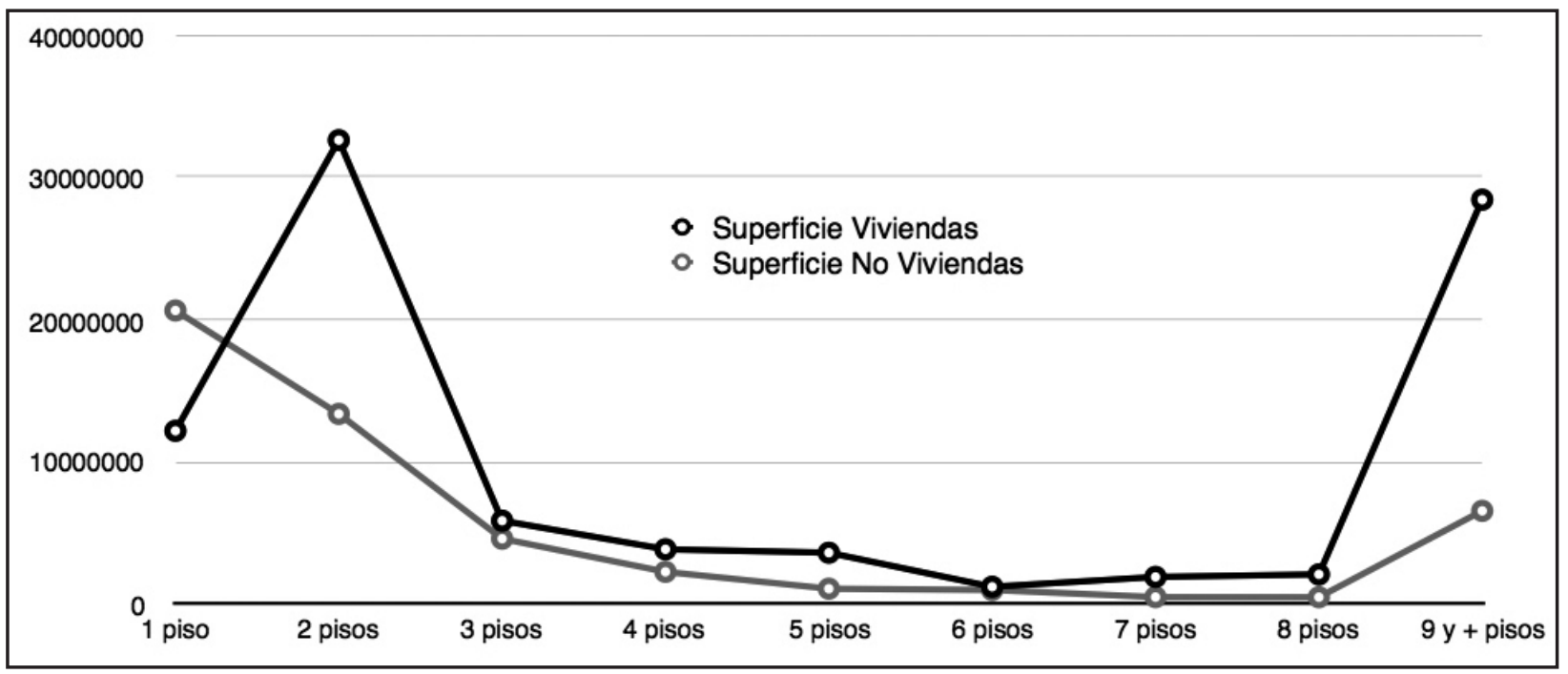

Fuente: Elaboración propia según estadísticas de edificación de INE.

Source: Elaborated by the author according to building statistics released by INE. 
pisos y más, asociadas al uso residencial representan el 31\% de lo edificado en el periodo, y las superficies del uso no residencial de la tipología participa en un 13\%. Las alturas intermedias, edificaciones de 3 a 5 pisos, solo capturan el 14,5\% de las superficies residenciales y el $15,7 \%$ de las superficies no residenciales.

La ausencia de edificación en altura en algunas comunas propone considerar la presencia de un modelo propiamente urbano de densificación de baja altura que las caracteriza, así como un modelo consolidado de densificación en altura presente en otras. La distribución de las superficies edificadas según la altura de las edificaciones grafica la radicalidad de este escenario (figura 5) donde la superficie edificada en las alturas intermedia palidece ante el desempeño de las alturas polares y todo el proceso es impulsado por el uso residencial. Esto expresa que en el periodo observado se han edificado dos tipos de modos urbanos: uno expansivo de baja altura y otro densificado en altura, cada uno con necesidades de implementación y gubernamentales diferentes. Dos polos de formas construidas, dos formas de ciudad.

Lo anterior se corrobora al observar la distribución de las materialidades utilizadas en edificaciones en el periodo considerado. Los datos indican que, al igual que las unidades de viviendas y las superficies, el 80\% de los volúmenes de materialidades se distribuye en la edificación de tres alturas: las de
14.5 percent of residential floor areas and 15.7 percent of non-residential structures built over the period under review.

The lack of high-rise buildings in some municipalities indicates the presence of an urban model based on the production of lowrise structures and the consolidation of high-rise construction in other areas. The distribution of built floor areas according to the height of buildings reveals the radical nature of this scenario (see Figure 5); in this case, the built floor areas of intermediate buildings pale into insignificance against the presence of low- and high-rise buildings. The latter suggests the emergence of two types of urban forms during the observed period: expansion (low-rise buildings) and densification (high-rise buildings), each of them with different implementation and governmental needs. This led to the emergence of two opposite built forms and types of city.

The above is corroborated by observing the distribution of building materials during the period under review. The data show that, as in the case of housing units and built floor areas, 80 percent of materials were used in the construction of three types of structures: one-storey buildings, two-storey buildings and buildings taller than nine stories (see Figure 6). Such a distribution shows that most of the constructions associated with these type of structures -houses (55.5 


\section{FIGURA 6. PORCENTAJE DE SUPERFICIE (M²) CUBIERTA POR MATERIALES PREDOMINANTES EN EDIFICACIONES DE OBRA NUEVA SEGÚN NÚMERO DE PISOS ENTRE 1990-2014 EN LA REGIÓN METROPOLITANA}

\section{FIGURE 6. PERCENTAGE OF BUILT FLOOR AREAS (SOUARE METERS) COVERED BY PREDOMINANT MATERIALS}

IN NEW BUILDINGS WITHIN THE METROPOLITAN REGION, DISTRIBUTED PER HEIGHT, 1990-2014

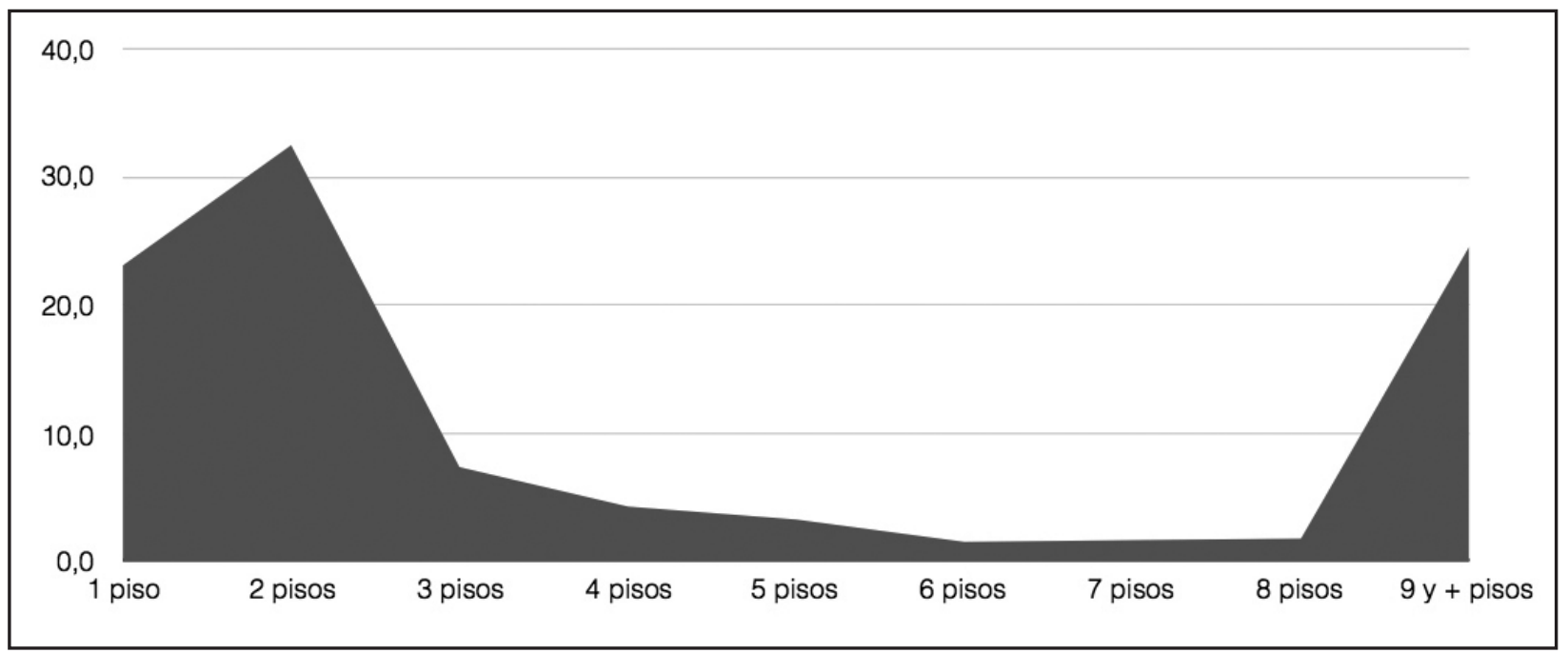

Fuente: Elaboración propia según estadísticas de edificación de INE.

Source: Elaborated by the author according to building statistics released by INE.

1, 2 y 9 pisos y más (figura 6). Esta distribución refleja que las tipologías mayoritariamente vinculadas a estas alturas: casas $(55,5 \%)$ y edificios (o torres; 24,5\%), han sido las formas construidas predominantes en la edificación desde 1990 en adelante, acaparando este alto porcentaje de volumen material. percent) and buildings (or towers; 24.5 percent) - represent the predominant built forms constructed since 1990; this explains the high percentage of building materials used in the construction of these buildings. 
Al analizar en detalle la distribución de las materialidades en las edificaciones (figura 7), es posible dar cuenta de que junto con las formas se configuran culturas materiales diferentes, es decir, modos composiciones y/o ensamblajes de materialidades que reproducen persistentemente determinadas posibilidades de uso, valor, mantenimiento e interacción dentro de la habilitación del espacio (Ingold, 2013; Mindrup, 2015). Mientras las edificaciones más bajas ocupan más ladrillo y son materialmente más heterogéneas, de forma que permiten mayores grados de intervención posterior y presentan un proceso de diseño abierto en el tiempo, las edificaciones más altas disparan el uso de hormigón, son más homogéneas en lo material y más cerradas a cualquier intervención posterior.

La heterogeneidad de los materiales predominantes en las edificaciones de baja altura implican una mayor variación en las soluciones arquitectónicas, en la forma construida, en los programas y en las duraciones de lo edificado, así como conllevan una plasticidad mayor respecto a la edificación, dado que su gestión material puede ser operada por un mayor número de actores y ello permite que las intervenciones a nivel de forma y composición sean más probables que en edificaciones de mayor altura (García, Torres y Tugas, 2008). Concreta y empíricamente a esta altura podemos apreciar modificaciones (reparaciones, ampliaciones, mejoras) que en edificaciones mayores son imposibles y, en el mismo sentido, es posible constatar
The analysis of the distribution of building materials (see Figure 7) reveals that there are different forms and material cultures; in other words, there are different compositions and/or mixtures of materials that constantly reproduce the specific use, value, maintenance and interaction within a given space (Ingold, 2013; Mindrup, 2015). While lower structures are made of bricks and show a heterogeneous form that enable the implementation of further modifications over time, higher constructions heavily rely on the use of concrete, are homogeneous in nature and do not enable the implementation of further modifications.

The heterogeneity of materials used to build low-rise structures implies architectural variety, different built forms, programs and durability; this feature also entails architectural flexibility since material management can be operated by different actors, enabling further modifications in terms of form and composition that cannot be conducted in higher buildings (Garcia, Torres E Tugas, 2008). Definitively and empirically speaking, modifications (such as repairs, expansions, improvements) are impossible to implement in higher structures; likewise, the disappearance of materials that are easy to obtain and use such as wood, stone and bricks, among others are noticed, a material culture socially supported by the retail market, hardware chains 
FIGURA 7. PORCENTAJE DE UTILIZACIÓN DE MATERIAL PREDOMINANTE EN EDIFICACIONES OBRA NUEVA SEGÚN NÚMERO DE PISOS ENTRE 1990-2014 EN LA REGIÓN METROPOLITANA

FIGURE 7. PERCENTAGE OF PREDOMINANT BUILDING MATERIALS USED IN THE CONSTRUCTION OF NEW BUILDINGS WITHIN THE METROPOLITAN REGION, DISTRIBUTED PER HEIGHT, 1990-2014

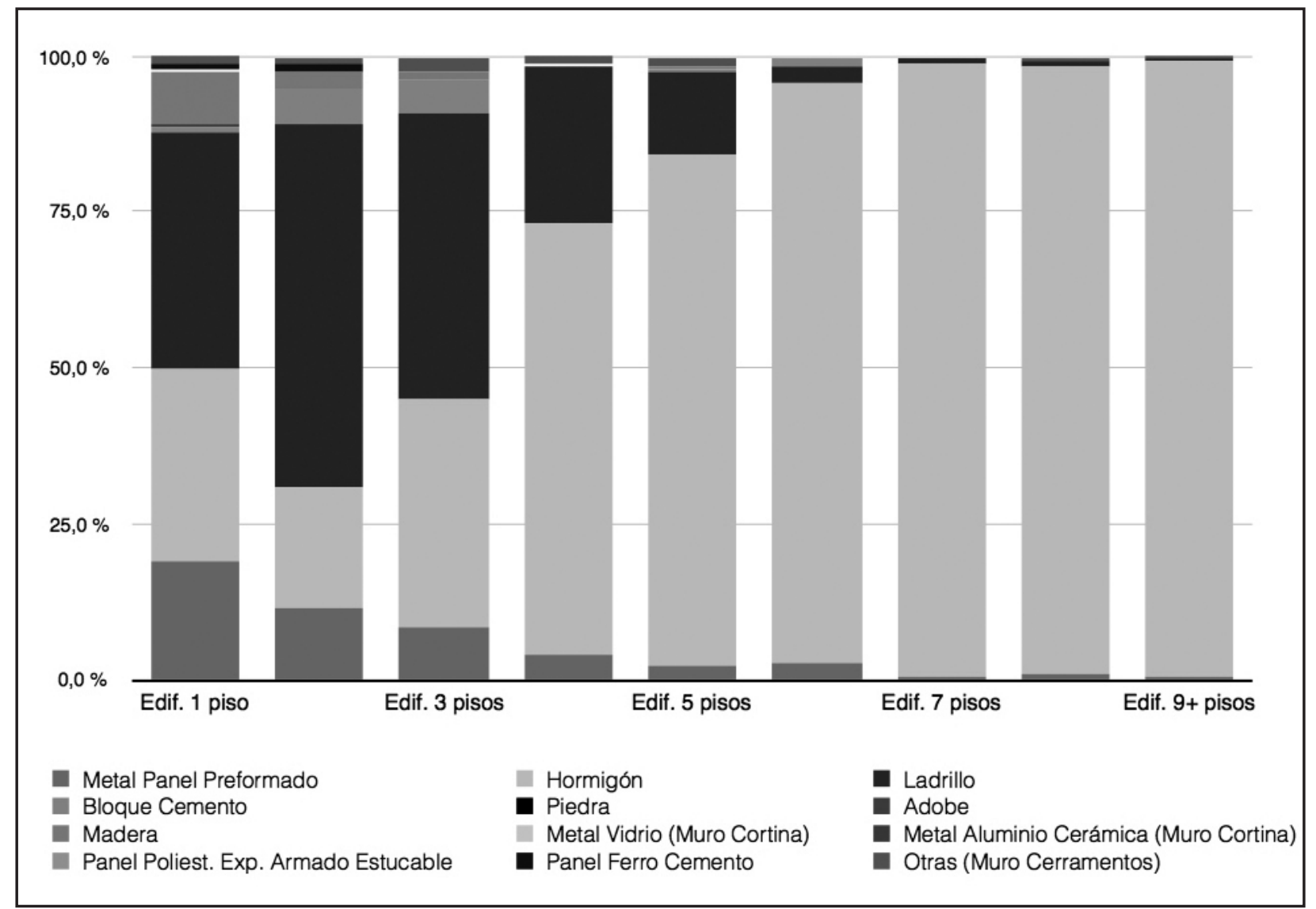

Fuente: Elaboración propia según estadísticas de edificación de INE.

Source: Elaborated by the author according to building statistics released by INE. 
predominancia de materiales que desaparecen en las alturas mayores, como la madera, la piedra y el ladrillo, entre otros, que son posibles de obtener y gestionar sin gran especialización ni ayuda tecnológica. Esta cultura material está soportada socialmente en el mercado minorista, en el retail de materiales edificatorios y en la multiplicidad de oficios ligados a esto.

La cultura material que expresan las edificaciones de mayor altura es más acotada en sus actores intervinientes, en sus formas y en las posibilidades de alteración y duración. También es distinta respecto a los recursos económicos y tecnológicos que moviliza. Su homogeneidad material es replicada en su forma construida, en sus procesos de producción, en la provisión de sus tecnologías y componentes, en sus programas de uso, entre otros aspectos. La homogeneidad material de estas edificaciones implica menor variación entre ellas, salvo por los adornos, pinturas y colores que las envuelven. Pero estos elementos, asociados a la duración del gusto estético, se mueven también homogéneamente dentro de los periodos y espacios en que las tendencias de este tipo persisten (Morcillo, 2012).

La preeminencia de tipologías de edificaciones polares, de alturas bajas y mayores, pone en evidencia los vectores que tensan la planificación de la ciudad y sus procesos inmobiliarios. Mientras la forma casa y la materialidad ladrillo (edificación de baja altura) están claramente asociadas a la and the different jobs associated to the building activity.

As for higher buildings, the material culture is characterized by a reduced number of intervening actors, in its forms and in the possibilities to modify these structures. Differences also exist in the allocation of economic and technological resources. The material homogeneity of these buildings is recreated in their built forms, production processes, provision of technology and use, among other aspects. This homogeneity also entails a lesser degree of differentiation among these constructions, except for the inclusion of different ornaments and colors. However, these elements are also homogeneous in terms of the periods and spaces dominated by esthetic trends (Morcillo, 2012).

The predominance of opposite types of buildings reveals the factors that affect city planning initiatives and real estate processes. While the house form and the brick type of material (lowrise constructions) are clearly associated with horizontal urban expansion, the building form and concrete type of material are common to vertical densification. The data show that such a tension is not only reflected in the new shape and skyline adopted by the city, but also in its material strategy.

The variation in the use of materials according to the height of structures and the flexibility 
extensión horizontal del espacio urbano; edificio y concreto son agentes de la densificación vertical. Los datos muestran que esta tensión no solo se expresa en la forma que adquiere la ciudad y su perfil (skyline) sino también en la estrategia material de la ciudad.

El dato de la variación de materialidades según la altura de la edificación y el evidente comportamiento plástico de la forma construida asociado a esto, evidencia que la planificación edificatoria implica directa o indirectamente una planificación material y que la elección de determinadas formas sobre otras condiciona la estrategia material de las ciudades (Benjamin, 2007; Mindrup, 2015). Como las edificaciones de mayor altura son más homogéneas materialmente (figura 7), incluyen un número limitado de materialidades excluyendo otras. Los edificios de altura, por decirlo de algún modo, expulsan a la madera de los mercados urbanos, por lo menos en sus versiones constructivas y estructurales. Vigas, tablones y tablas no son abundantes en las ferreterías ni son necesarias las barracas cercanas

Lo anterior expone la fuerte relación entre el diseño de la forma construida, contenido en la arquitectura, y la ciudad a la que da forma, corroborando la centralidad del planeamiento material en este proceso (Thomas, 2007). Materialmente los edificios altos se parecen entre sí y expresan una misma cultura material que no ha experimentado of built forms reveal that building planning processes involve -either directly or indirectly-a material planning process and that the choice of certain forms determines the material strategy of cities (Benjamin, 2007; Mindrup, 2015). Since tall buildings are materially homogeneous (see Figure 7) they include a limited number of materials to the detriment of others. Highrise buildings have excluded wood from urban markets, at least in their constructive and structural form. Rafters, beams and boards are difficult to find in hardware stores and there is no requirement to have nearby wood depots.

The above reveals the strong relationship that exists between built forms -found within the architectural sphere- and the transformed city; this corroborates the central role played by material planning (Thomas, 2007). In material terms, high-rise buildings resemble each other and share a material culture that has not been significantly modified during the period under review; on the other hand, houses and buildings as tall as four stories are made of different materials and their ornamental, improvement and maintenance culture is heterogeneous in nature. The latter structures provide clear examples of esthetic and segregation.

Despite sharing the same form and building materials, high-rise constructions differ when it comes to property ownership as they 
cambios significativos durante este periodo, mientras las casas y edificaciones de hasta cuatro pisos, expresan materialmente una mayor variación en sus componentes materiales y sus culturas de hermosamientos, mejora y mantenimiento. Grafican mejor los gustos y la segregación.

Además de lo anterior, la homogeneidad de forma y materialidad de las edificaciones de altura mayor no se ve acompañada en la propiedad de las mismas, ya que en ese aspecto resultan ser más heterogéneas que las de altura menor: requieren de disposición de recursos que en lo general son provistos por números altos de actores, requieren de una densidad social que no puede sino ser heterogénea y requiere de comunidades capaces de ponerse de acuerdo para que su habilitación funcione.

\section{La tendencia socio espacial en la distribución los edificios residenciales de altura}

En consideración a lo anterior cabe señalar que la edificación en altura de los últimos 25 años no se distribuye por igual en todas las comunas de la región. Solo 28 de las 52 comunas de la región presentan viviendas en edificaciones sobre los nueve pisos, y el 25\% de ellas se encuentran en la comuna de Santiago. Los datos observados son claros en are more heterogeneous than their low-rise counterparts: they require resources provided by different actors, a heterogeneous social density and widespread agreement for their proper implementation.

\section{Socio-Spatial Trends within the Distribution of High-Rise Buildings}

Considering the above, it is worth mentioning that the construction of high-rise buildings has not been equally distributed within the Metropolitan Region during the period under review. Only 28 out of the 52 municipalities have buildings taller than nine stories and 25 percent of buildings are located in the municipality of Santiago. The analyzed data clearly show that the construction of high-rise buildings and the verticalization phenomenon is taking place in a handful of municipalities.

Likewise, 52.8 percent of dwellings built in buildings taller than nine stories are found in two municipalities: Santiago and Las Condes (see Figure 8). The municipality of Santiago accounts for 36.2 percent of dwellings built in high-rise buildings -143,652 units-, twice as much as 
indicar que la edificación en altura, y por tanto la verticalización de la ciudad, se concentra en pocas comunas.

Según estos, el 52,8\% de la vivienda en edificaciones de nueve y más pisos de altura está ubicada en dos comunas: Santiago y Las Condes (figura 8). La comuna de Santiago, por sí sola, explica el 36,2\% de las viviendas en altura con 143.652, doblando a Las Condes. A pesar de ello, su superficie edificada $\left(7.359 .105 \mathrm{~m}^{2}\right)$ es levemente menor respecto a Las Condes $\left(7.873 .017 \mathrm{~m}^{2}\right)$. Esto implica que en la comuna de Santiago se han ubicado el doble de viviendas en la mitad de la superficie ocupada en la comuna de Las Condes, lo cual es la seña de su proceso densificatorio.

La comuna de Santiago, que presentaba una variación poblacional intercensal del -13,1\% entre 1992 y 2002, revierte esa tendencia en la década siguiente con una variación de 53,4\%. En el caso de Las Condes, a contrario, la década de 2002 a 2012 presenta una variación intercensal de población de 13,8\%, variación positiva, pero de menor intensidad que los 20,1\% presentados en la década anterior.

Como evidencia la figura 8, si bien son 28 las comunas que presentan viviendas en edificaciones mayores de nueve pisos, estas 10 comunas concentran el 93,8\% de estas viviendas. Esto demuestra la alta concentración de edificios de altura solo en algunas comunas, en particular pericentrales y de
Las Condes. However, its built area $(7,359,105$ square meters) is slightly smaller than that of Las Condes (7,873,017 square meters). This suggests that in Santiago double the number of dwellings have been built in half of the built floor area when compared with Las Condes. Such a phenomenon reveals the presence of a densification-based process.

Over the period 1992 to 2002, the municipality of Santiago had an inter-census population variation of -13.1 percent; however, this trend was reversed during the following decade with a variation of 53.4 percent. As for Las Condes, the 2002-2012 inter-census period showed a population variation of 13.8 percent which, despite being a positive variation, was smaller than the 20.1 percent recorded during the previous decade.

As Figure 8 indicates, while there are 28 municipalities with buildings taller than nine stories, 93.8 percent of these structures are found in 10 municipalities. The latter shows the high concentration of high-rise buildings in a handful of middle- and high-income pericentral municipalities, with the exception of Estación Central, Independencia and Recoleta. Promoted by residential demand, the highrise densification process experienced by these municipalities has been a subject of debate 
FIGURA 8. NÚMERO Y SUPERFICIES DE VIVIENDA EN EDIFICACIONES DE OBRA NUEVA DE 9 Y MÁS PISOS, SEGÚN COMUNAS, TOTAL 1990-2014

FIGURE 8. NUMBER AND BUILT FLOOR AREAS OF DWELLINGS BUILT IN NEW BUILDINGS TALLER THAN NINE STORIES, DISTRIBUTED PER MUNICIPALITY, 1990-2014

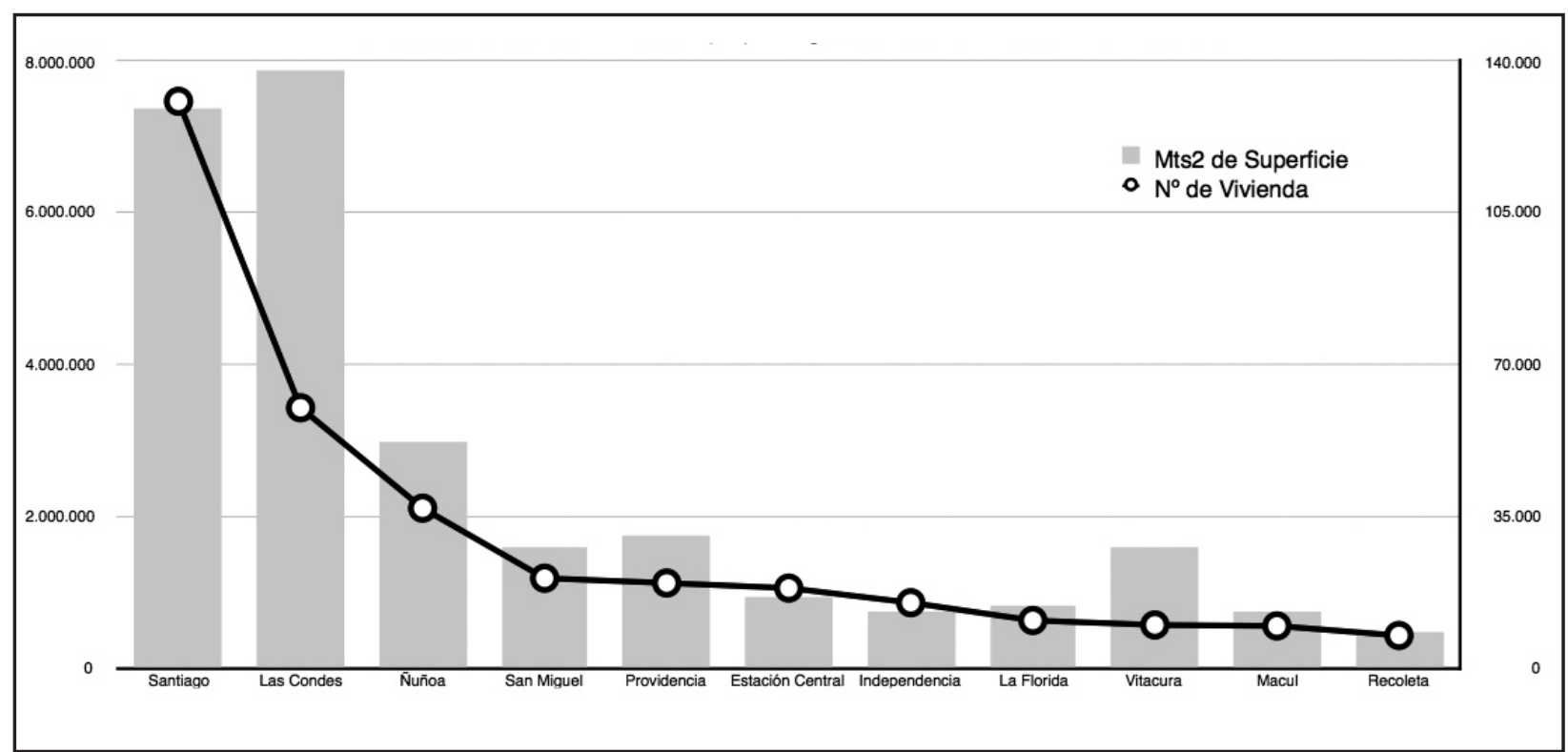

Fuente: Elaboración propia según estadísticas de edificación de INE.

Source: Elaborated by the author according to building statistics released by INE. 
hogares con ingresos medios y altos aunque hay algunas comunas de ingresos medios como Estación Central, Independencia y Recoleta. La densificación en altura en estas comunas, impulsado por la demanda residencial ha presentado controversias en el uso de la forma construida evidenciando un límite socio-técnico para la forma construida centrado en las comunidades que las habitan y en sus capacidades para asumir el cuidado de la misma.

Lamentablemente, se carece del dato específico de unidades de edificios de altura en el Gran Santiago, pero a pesar de ello es posible aproximar los números de su efecto sobre la ciudad. Saber, por ejemplo, en qué comunas este tipo de formas son viables o no, en cuales se presentan mayor tipo de controversias y/o como se distribuyen la altura en las comunas de la ciudad. Esto conlleva también la posibilidad de determinar qué comunas se encuentran más verticalizadas en relación con las formas arquitectónicas construidas en su interior.

Considerando la participación de cada comuna en los datos de superficie edificada por piso en la Región Metropolitana de Santiago entre 1990 y 2014 se elaboró un índice que expresara la intensidad comparada de la edificación en altura (verticalización). Sus resultados (figura 9) indican que solo 11 de las 52 comunas de la Región presentan una alta o muy alta verticalización, localizando el fenómeno en ellas e implicando que este no regarding the use of built forms. This reveals the presence of a socio-technical barrier to residents and their capacities to deal with such an issue.

Unfortunately, there is no data about the precise number of high-rise buildings in Greater Santiago; however, it is possible to theorize about their impact on the city. For instance, we could determine the municipalities with the capacity to develop this type of built forms, the most conflictive areas and/or the distribution of highrise constructions within the city. This implies the possibility to identify the most verticalized municipalities and the architectural forms built within them.

The presence of each municipality in the collection of data regarding built floor areas within the Metropolitan Region, distributed per height over the period 1990 to 2014, was used to elaborate an index about the compared intensity of high-rise construction (verticalization). The results (see Figure 9) indicate that only 11 out of the 52 municipalities located within the Metropolitan Region show high or very high verticalization rates; this suggests that the highrise phenomenon is taking place in peri-central 
FIGURA 9. VERTICALIZACIÓN DE LAS EDIFICACIONES EN COMUNAS DE LA REGIÓN METROPOLITANA 1990-2014 FIGURE 9. VERTICALIZATION OF HIGH-RISE BUILDINGS WITHIN THE METROPOLITAN REGION, 1990-2014

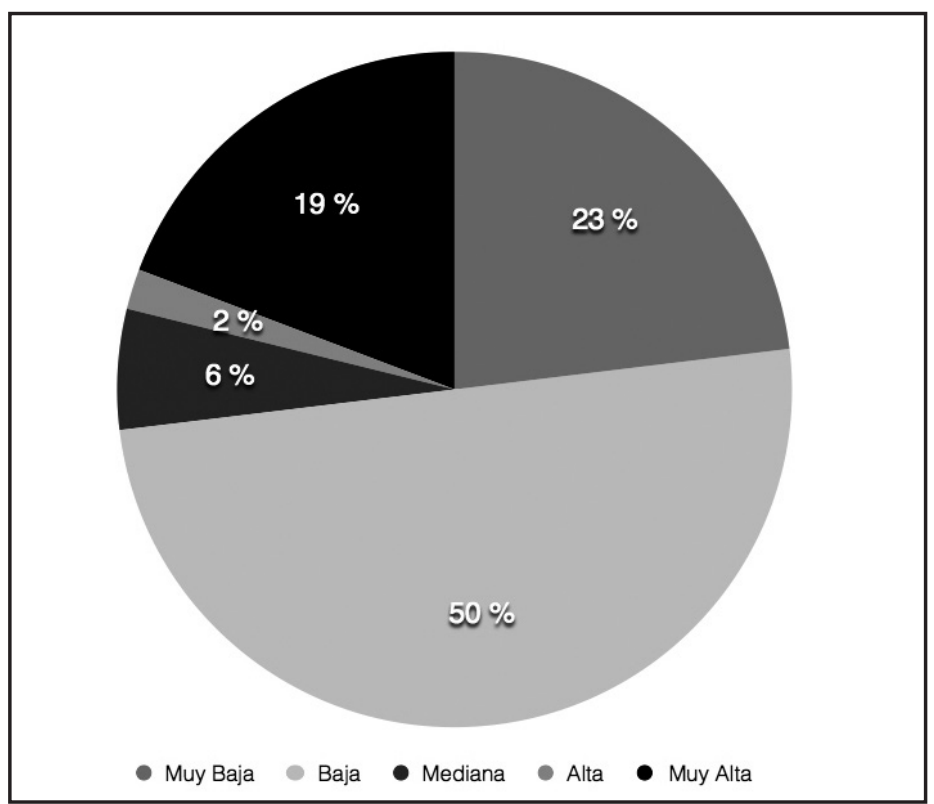

Fuente: Elaboración propia según estadísticas de edificación de INE.

Source: Elaborated by the author according to building statistics released by INE. 
sobrepasa los límites pericentrales, corroborando los datos presentados en la figura $8^{2}$.

Es de suponer que estas 11 comunas presentan requerimientos no solo diferentes, sino también de mayor complejidad que comunas con menos edificios de altura, pues la verticalización de sus edificaciones residenciales conlleva tanto densificación poblacional como un aumento en la carga de su estructura de servicios, a nivel de predios y de manzanas. Esto trae consigo una mayor necesidad de coordinación entre los actores que movilizan la oferta y la demanda de movilidades, gestión de basuras, agua, gas, electricidad entre otros elementos críticos para la habilitación técnica de los espacios residencia. La persistencia de estas coordinaciones entre entidades sociales y técnicas implica tanto prácticas de gestión, provisión y mantenimiento, como su institucionalización mediante normativas particulares, lo que debiese configurar regímenes socio-técnicos específicos en tales comunas.

Pero esto no siempre es así. Por ejemplo, ninguna de estas comunas considera en sus esquemas de gobierno (normativas e instituciones) preocupación por la movilidad vertical interna. Ninguna, salvo Lo Barnechea debido a la instalación de ascensores urbanos en las laderas del Cerro 18, pero esta comuna no se encuentra en el grupo de

2 Las comunas con estos valores en el índice son Providencia, Santiago, Estación Central, Independencia, Las Condes, Macul, Ñuñoa, Recoleta, San Joaquín, San Miguel y Vitacura. areas, corroborating the data showed in Figure $8^{2}$.

It should be assumed that these 11 municipalities have different and more complex requirements than low-rise constructions since verticalization implies population densification and an increase in the provision of services. This creates the need for greater coordination among those involved in the mobility market and waste, water, gas and electricity management, among other critical elements required for the technical implementation of residential spaces. The presence of this coordinated activity between social and technical entities implies the creation of management, provision and maintenance practices as well as institutionalization measures through the development of special regulations; this should lead to the creation of specific sociotechnical systems.

However, this is not always the case. For instance, none of these municipalities is concerned (at a regulatory and institutional level) about internal vertical mobility. None of them, except Lo Barnechea, given the implementation of urban elevators on Cerro 18, which is not included in the group of municipalities affected by residential verticalization and where mobility is

2 These municipalities are: Providencia, Santiago, Estación Central, Independencia, Las Condes, Macul, Ñuñoa, Recoleta, San Joaquín, San Miguel and Vitacura. 
comunas donde la verticalización de las edificaciones residenciales y con ello de la movilidad es un fenómeno realmente existente en su entramado urbano (Brenner, 2004; Brenner, Madden, y Wachsmuth, 2011). Tampoco es posible señalar existencia de normativas sobre uso de recursos eléctricos, gasíferos o hídricos a nivel comunal y es porque todo ello queda bajo el dominio de relaciones de consumo entre privados, lo cual no considera los posible efectos colectivos de estos consumos.

A contrario de lo que se podría suponer debido a la proliferación de su forma y las similitudes de sus perfiles y de su composición material, los edificios de altura no constituyen una forma socialmente homogénea, pues sus comunidades no lo son. Hay variaciones en su interior que hacen que un edificio de X pisos en Santiago sea más densificado que uno de igual número de pisos en Las Condes, y que uno ubicado en la comuna de Estación Central sea más densificado que los otros dos. Sumado a esto, otros factores sociales influyen en constituir comunidades diferentes en cada uno de los casos. La condición socioeconómica de sus administraciones y de sus habitantes también difiere, como lo hacen los recursos de los que disponen, lo que propone que cada comuna enfrenta problemas diferentes con el fenómeno de la edificación en altura.

Mientras para una comuna como Estación Central, el fenómeno es claramente asociable a lo residencial y gestionable bajo ese parámetro, para una a phenomenon (Brenner, 2004; Brenner, Madden $\mathcal{E}$ Wachsmuth, 2011). Likewise, it is impossible to identify the presence of regulations about the use of electricity, gas or water at municipal level; this is because these services are controlled by private actors who seem not to be aware of the collective consequences of the use of these resources.

Contrary to what we may think about the proliferation, similarity and shared material composition of high-rise buildings, they are not part of a socially homogeneous form as their local resident communities also lack homogeneity. There are some variations that turn an n-story building located in Santiago to be denser than a building consisting of the same $n$ stories located in Las Condes; if located in Estación Central, this very n-story building would be even denser than in the two previous locations. Added to this is the presence of social factors that determine the creation of different types of communities. The socioeconomic level, resources of local administrations and dwellers also differ, suggesting that each municipality faces different issues regarding the high-rise phenomenon.

While in Estación Central this phenomenon is clearly associated with residential issues, in Las Condes it is also related to a commercial and corporate phenomenon. This leads to the creation of different governmental systems 
comuna como Las Condes, la edificación en altura también tiene que ver con un fenómeno comercial y corporativo. Esto conlleva la configuración de regímenes de gobierno distintos en cada caso, y a pesar de que la forma construida nos parece similar, cada edificio en altura representa un problema de gubernamentalidad particular, es decir, se presenta como una configuración política determinada dentro de la cual operan un conjunto de métodos de control de las cosas y de las personas que le son específicos (Foucault, 1999; 2006) ${ }^{3}$. Por de pronto hay una alta heterogeneidad de actores involucrados en la gestión de estas unidades. Organizar y poner de acuerdo a propietarios, arrendatarios, administradores, conserjes, servicios técnicos, y enrolarlos en el cuidado de las habilitaciones técnicas del espacio constituido en el edificio, que requiere de coordinaciones que sobrepasan lo meramente administrativo.

Una casa es un objeto de gobierno distinto a un edificio, y tanto la densificación misma como el

3 La comprensión de la forma construida y de las formas urbanas en tanto formas de gobierno de las cosas, está tempranamente presente en la sociología ya sea en el caso de Max Weber (la dominación no legítima), de Emile Durkheim (el hecho social materializado) o Alfred Weber (la localización de las industrias). En la literatura más actual se enmarcan también aquí los trabajos de Thomas Gieryn ("What Buildings do", 2002; "Radical space: building the house of the people", 2005); Albena Yaneva ("Scaling up and down: extraction trials in architectural design", 2005; "Urban controversies and the making of the social", 2012) y Michael Guggenheim ("Building memory. Architecture, networks and users", 2012), entre otros. and, despite the fact they supposedly share the same built forms, each high-rise building has specific governability problems; in other words, there is a political configuration defined by particular control methods and relevant actors (Foucault, 1999; 2006) ${ }^{3}$. There is a high level of heterogeneity among the actors involved in the administration of these units. Organizing and establishing agreements among owners, tenants, managers, concierges and technical services to involve them in the proper technical implementation of the space built within the building require coordinating capacities that transcend the administrative sphere.

Governing a house is not the same as governing a building and densification, which is materialized through built forms, involves a complex form of administration that requires local government to deal with unexpected demands. Controversies regarding this aspect are becoming increasingly common, some of them are associated with the

3 The earliest sociologic references to the governmental analysis of built forms and urban forms can be found in the works of Max Weber (non-legitimate domination), Emile Durkheim (materialized social fact) or Alfred Weber (the location of industries). There are also current references to this topic in the works of Thomas Gieryn (What Buildings Do, 2002 and Radical Space: Building the House of the People, 2005); Albena Yaneva (Scaling Up and Down: Extraction Trials in Architectural Design, 2005 and Urban Controversies and the Making of the Social, 2012) and Michael Guggenheim (Building Memory. Architecture, Networks and Users, 2012), among others. 
que esta sea realizada mediante una forma construida que lleva asociada una gobernanza compleja deposita en los gobiernos locales una demanda de dimensiones insospechadas de este insumo. Controversias originadas en este aspecto son cada vez más comunes, algunas asociadas a las sobre ocupación de los departamentos, otras a conflictos de usos de instalaciones, pero que derivan en controversias de movilidad, de convivencia, de administración, de provisiones de recursos, entre otras (Ng, 2010; Yau, 2012). Problemas a nivel de las instalaciones como las circulaciones operadas por ascensores, la autoproducción energética o la eliminación de aguas negras y basuras; o de problemas a nivel de uso, la tenencia de mascotas y de otros aspectos que impactan en la conformación de comunidades en torno a estas formas habitacionales ${ }^{4}$.

Es claro que este tipo de cambio urbano (verticalización) requiere de nuevas habilidades en el gobierno de la ciudad y de nuevas fuentes información, dado que eclosiona tanto el modelo concéntrico de planificación como el modelo de predial de información toda vez que se expresa no solo en plano (y la ocupación del predio) sino también en la elevación (forma construida). La manera como se ve la ciudad es clave para entender qué nos

4 Ver “Los problemas de los administradores para reparar las fallas en los edificios" en El Mercurio, 13 de marzo de 2016. occupation of dwellings and others are related to the use of amenities; however, all of them derive from mobility, coexistence, administration and provisioning issues, among others ( $\mathrm{Ng}, 2010$; Yau, 2012). There are also problems associated with the operation of elevators, energy selfproduction or waste-wastewater disposal; likewise, issues regarding the use of dwellings or the presence of pets affect the establishment of communities within these types of constructions ${ }^{4}$.

It is clear that this type of urban change (verticalization) requires new capacities on the part of city governments and new sources of information, this is because there is an emergence of new concentric planning models and property information models within a context where the two of them are expressed not only in space (occupation of dwellings) but in terms of elevation (built forms). The appearance of the city is essential to understand its spatial culture, this being a key element within the planning process.

However, the data show that the main driving force behind the high-rise phenomenon is the construction of an increasing number of dwellings; therefore, this is mainly a residential and densification-based phenomenon. This type of densification is being replicated within the

$4 \quad$ Please refer to "Issues faced by administrations when repairing failures in buildings", El Mercurio, March 13, 2016. 
expresa sobre su cultura espacial y es lo que permite su planificación.

Con todo, los datos muestran que el principal impulso para la edificación en altura en la ciudad es la ubicación de viviendas en ellos y, por tanto se trata de un fenómeno mayoritariamente residencial y densificatorio. Este tipo de densificación contagia al conjunto de comunas del pericentro, pero no sigue, necesariamente la lógica pericentral. Una duplicación del centro laboral en la comuna de Las Condes ha llevado consigo el aumento del suelo en otras comunas, que, por su ubicación cercana, han comenzado a densificarse también con edificaciones de altura, como Recoleta, Independencia, Nuñoa, La Reina, Macul y La Florida. Como correlato, no son pocas las comunas que muestran completa ausencia de edificaciones de altura privilegiando las edificaciones en baja altura.

\section{Conclusiones}

La consolidación de datos de las encuestas de edificación del INE permitió analizar el comportamiento de variables implicadas en el proceso durante un periodo de 25 años (1990 y 2014) y facilitó la observación de tres características del mismo: su tendencia a ser protagonizado por edificaciones de altura, el mayoritario sentido residencial de estas y

44 revista invi 32(90) : 9-50, agosto 2017 group of peri-central municipalities disregarding the peri-central concept itself. The recreation of a business district in Las Condes has led to an increase in the price of land in other municipalities which, due to proximity reasons, are also experiencing a densification process based on the construction of high-rise buildings; this is the case of Recoleta, Independencia, Nuñoa, La Reina, Macul and La Florida. Additionally, an important number of municipalities have no high-rise buildings as they favor the presence of low-rise constructions.

\section{Conclusions}

The analysis of data released by the building surveys conducted by INE enabled the exploration of the variables associated with the building process over a period of 25 years (1990 to 2014) and made it possible to observe its main three characteristics: the predominance of high-rise buildings, the prevalence of the construction of residential units and its reduced socio-spatial distribution. However, although this phenomenon is only taking place in 11 out of the 52 municipalities located within the Metropolitan Region, there is an intense building process marked by the massive construction of residential units. 
su distribución socio especialmente acotada. Pero, aun cuando el fenómeno de la verticalización se reduzca a 11 de las 52 comunas de la región, es intenso en términos edificatorios y cada vez más masivo en términos de residencialidad.

La principal pregunta, que motivan estas tres características, inquiere sobre el riesgo que la proliferación de edificaciones residenciales de altura presenta para las comunas que las acogen, en especial, para aquellas que han sustentado su densificación en estas formas arquitectónicas y cuya composición socioeconómica no corresponde mayoritariamente a altas rentas. Comunas con recursos municipales menores que difícilmente podrán asumir la carga de funcionamiento de estas edificaciones si sus comunidades fallan en la coordinación y provisión de recursos de movilidad, gestión de desechos, consumos energéticos u otros; o que no pueden solventar la inversión pública que implica aumentos masivos en los flujos de automóviles o demandas de espacios públicos.

Las edificaciones de altura, sobre todo si su uso es residencial, conllevan cargas intensivas de usos de servicios y requerimientos técnicos que deben de ser soportadas y distribuidas socialmente. Como formas de vivienda colectiva masiva demandan además de organizaciones sociales y técnicas que no está claro que puedan por sí mismas proveerse, y que es necesario que sean integradas como
The main doubt about these three characteristics is associated with the risks involved in the proliferation of high-rise structures in lowerincome municipalities. Districts with fewer resources may face difficulties when assuming the responsibility to operating these buildings if their owners fail in the coordination and provision of vertical mobility, waste disposal or issues of energy consumption, among others; or if they fail to properly fund public investment to tackle the massive increase in vehicular traffic or the demands for the construction of public spaces.

High-rise buildings, especially those intended for residential purposes, involve an increased use of services and technical requirements that should be supported and distributed on a social basis. As forms of collective housing they also require the creation of self-sufficient social and technical organizations that should be incorporated within the urban governance sphere, especially at the municipal level.

Since there is an increasing number of people (and families) living in high-rise buildings, they should be involved -both as dwellers and contributors- in the maintenance of these architectural forms that require collective participation and funding to operate properly. This means that each building needs a specific type of administration, the latter understood as 
factores dentro de la gobernanza urbana, sobre todo a nivel comunal.

Cada vez más personas (y familias) viven en edificios y deben participar como habitantes y como sostenedores de formas arquitectónicas que demandan participación y financiamiento colectivo para funcionar adecuadamente en términos residenciales. Esto hace que cada edificio requiera de un modo específico de gobierno, entendido esto como un conjunto de prácticas, normas y legitimidades necesarias para funcionar óptimamente.

El aumento de estas edificaciones en un comuna es también el aumento de sus modos de gobiernos, de sus aciertos si funcionan o de sus fallos, si no lo hacen; y ligan la forma arquitectónica con otros territorios de gobierno, como las propias comunas pues la carga de sus requerimientos recae finalmente en la estructura vial y de servicios de la comuna.

Esto lleva a una segunda conclusión, más allá de la primera ligada al riesgo, y que radica en que los fenómenos mencionados se producen en una escala arquitectónica, no solo predial, y requieren de una consideración analítica similar a la se ocupó en otros casos de vivienda colectiva como el cite, la villa o la población, en tanto formas de ocupación espacial y no solo tipología de uso de suelo (Servicio Nacional de Estadísticas y Censos, 1952, p. 65; Garcés, 2002). Si bien existe como imagen coloquial, el considerar algunos edificios como poblaciones o guetos verticales, lo cierto es que no a series of practices, regulations and legalities intended to ensure proper operation.

The increase in the number of these constructions within a specific municipality also implies the emergence of different forms of government, which may either succeed or fail. Likewise, they relate their architectural forms to other governmental spheres; this is the case of municipalities as new buildings require the provision of more services and road structures.

This leads to a second conclusion that transcends the risk sphere; in this case, the above phenomena do not only take place at the residential level, but also at the architectural level, demanding the same analytical attention as other types of collective housing such as tenement houses, villages and slums, both in terms of spatial occupation and land use (Servicio Nacional de Estadísticas y Censos, 1952, p. 65; Garcés, 2002). While some high-rise structures are colloquially referred to as vertical ghettoes, they have not been properly explored as their horizontal counterparts as they have been ignored by recent local research (Jobet, Martínez \& Poduje, 2015; Mattos, 2015).

On the other hand, the governmental sector remains vigilant about this process. There has been speculation over the last two years about the participation of the State in the real estate market through the purchase of apartments 
han sido objeto del mismo enfoque investigativo que se aplica a sus homólogos horizontales, ya que no constituyen como tales unidades de observación de investigaciones locales recientes (Jobet, Martínez y Poduje, 2015; Mattos, 2015).

Los organismos gubernamentales, por su parte, se han mantenido expectantes respecto del proceso. Se ha especulado durante los últimos dos años sobre la entrada del Estado al mercado inmobiliario mediante la compra de departamentos para su arriendo social, sobre la modificación del límite de altura a cambio de la existencia de departamentos sociales dentro de los edificios, sobre la de recuperación de plusvalías que sirva como mecanismo de atenuación de la gentrificación de los paños centrales $^{5}$, entre otras propuestas que no llegan todavía ser concretas, a pesar de encontrar apoyo en los actuales gobiernos comunales, en la Intendencia Regional y en el MINVU. Estas propuestas de densificación buscan salida a una posible disminución de la demanda constructiva, sin embargo minimizan el efecto que puede tener la proliferación de las edificaciones de altura en la gobernanza urbana.

Se hace necesario considerar a los edificios de altura como unidades funcionalmente compuestas, heterogéneas y viables, que constituyen un espacio de aparición pública de un fenómeno socio técnico

5 Ver "A 20 años del plan de renovación urbana: cómo cambio el perfil del habitante de Santiago Centro". En El Mercurio, Domingo 27 de julio de 2014. for social renting purposes, the modification of height limits in return for the creation of social apartments within new buildings and the recovery of added value to control gentrifying processes in central areas ${ }^{5}$, among other proposals that still need to be materialized-despite being supported by current municipal governments, the Regional Government and MINVU. These densificationbased proposals are intended to mitigate construction demands; however, they reduce the effect of the proliferation of high-rise buildings on urban governance.

Then it is necessary to regard high-rise buildings as functionally organized, heterogeneous and viable units that reveal the emergence of a sociotechnical phenomenon associated with urban scale and the massive occupation of built heights (Gehl, 2010; 2011; Allen, 2013). Considering high-rise buildings as objects of urban analysis does not only imply understanding their effect -form- on the urban scale (Brenner, 2004; Brenner et al., 2011; Cuthbert, 2006), but also the effect of relevant actors (Ingold, 2007; 2013) on the urban scale and its environment.

5 Please refer to "Twenty Years after the Creation of the Urban Renewal Plan: Evolution of the Inhabitants of Santiago Centro", El Mercurio, July, Sunday 27, 2014.

revista invi32(90) : 9-50, august 2017 
asociado a la escala urbana y masiva del habitar en una altura construida (Gehl, 2010; 2011; Allen, 2013). Considerar a los edificios de altura como unidades de análisis urbano no solo implica considerar el efecto de su forma sobre la escala urbana (Brenner, 2004; Brenner et al., 2011; Cuthbert, 2006), sino también el efecto que el tejido de actores (Ingold, 2007; 2013) implicados en su funcionamiento tiene sobre la escala urbana y sobre su entorno.

\section{Bibliografía}

Abbott, J. R. (2000). Louis Sullivan, architectural modernism, and the creation of democratic space. The American Sociologist, 31(1), 62-85. doi:10.1007/ s12108-000-1005-0.

Aguirre González, M. (2012). La arquitectura moderna en Chile (1907-1942). Santiago: Universitaria.

Allen, E. (2013). Cómo funciona un edificio. Principios elementales. Barcelona: Gustavo Gili.

Araujo, R. (2012). Construir en altura. Sistemas, tipos y estructuras. Barcelona: Reverté.

Asociación de Arquitectos (1934). Publicaciones de los principales acuerdos y conclusiones habidas en el primer Congreso Nacional de Arquitectura y Urbanismo celebrado en diciembre de 1934. Santiago: H. Galvez y C. Conca.
Benjamin, A. (2007). Plans to Matter. Towards a History of Material Possibility. En K. L. Thomas (Ed.), Material Matters. Architecture and Material Practice (pp. 14- 27). Abingdon: Routledge.

Brenner, N. (2004). New States Spaces. Urban Gobernance and the Rescaling of Statehood. New York: Oxford University Press.

Brenner, N., Madden, D. J. y Wachsmuth, D. (2011). Assemblage urbanism and the challenges of critical urban theory. City, 15(2), 225-240. doi:13604813.2011.568717

Cuthbert, A. (2006). The Form of Cities. Political Economy and Urban Design. Oxford: Blackwell.

Foucault, M. (1999). Ética, estética y hermenéutica. Barcelona: Paidós.

Foucault, M. (2006). Seguridad, territorio, población. Curso en el Collège de France (1977)-1978). Buenos Aires: Fondo de Cultura Económica.

Garcés, M. (2002). Tomando su sitio: el movimiento de pobladores de Santiago, 1957-1970. Santiago: LOM.

García-Huidobro, F., Torres Torriti, D. y Tugas, N. (2008). ¡El tiempo construye! Barcelona: Gustavo Gili.

Gehl, J. (2010). Cities for people. London: Island Press.

Gehl, J. (2011). Life between buildings. Using public space. London: Island Press.

INE. (2003a). Anuario de edificación 2001. Santiago: INE.

INE. (2003b). Anuario de edificación 2002. Santiago: INE.

INE. (2004). Anuario de edificación 2003. Santiago: INE.

ARTICLE: Verticalization. High-rise buildings in the Santiago Metropolitan Area (1990-2014)/Jorge Eduardo Vergara Vidal 
INE. (2006). Manual para el análisis del formulario único de edificación Recuperado de http://www.ine.cl/ canales/chile_estadistico/estadisticas_economicas/edificacion/metodologia/pdf/metodologial. pdf

INE. (2007). Metodología encuesta de edificación mensual (pp. 28). Recuperado de http://www.ine.cl/ canales/chile_estadistico/estadisticas_economicas/edificacion/metodologia/pdf/METODOLOGIA\%20EDIFICACION\%20_FINAL.pdf

Ingold, T. (2007). Lines. A brief history. London: Routledge.

Ingold, T. (2013). Making. Anthropology, archaeology, art and architecture. London: Routledge.

Jara, C. (2015). Ciudad, sociedad y acción gremial. Los arquitectos de Chile en el siglo XX. Santiago: LOM.

Jobet, N., Martínez, J. P. y Poduje, I. (2015). Infilling: cómo cambio Santiago y nuestra forma de vivir la ciudad. Santiago: Inmobiliaria Almagro; Atisba.

Koolhaas, R. (2004). Delirio de Nueva York. Barcelona: Gustavo Gili.

Koolhaas, R. (2014). Acerca de la ciudad. Barcelona: Gustavo Gili.

Mattos, C. A. d. (2015). Revolución urbana. Estado, mercado y capital en América Latina. Santiago: RIL Editores.

Mindrup, M. (2015). The material imagination. Reveries on architecture and matter. Surrey: Ashgate.
Morcillo Núñez, F. (2012). Color y biopolitica. Una mirada a los colores de Santiago. (Seminario de investigación), Santiago: Facultad de Arquitectura y Urbanismo Universidad de Chile.

$\mathrm{Ng}, \mathrm{E}$. (2010). Designing high-density cities for social and environmental sustainability. London: Earthscan.

Sahady Villanueva, A. (2014). Mutaciones del patrimonio arquitectónico de Santiago de Chile. Una revisión del centro histórico. Santiago: Universitaria.

Servicio Nacional de Estadísticas y Censos (1952). XII Censo Nacional de Población y I de Vivienda. Levantado el 24 de Abril de 1952. Santiago: Autor.

Sullivan, L. H. (1896). The tall office building artistically considered. Lippincott's Magazine (57), 403-409.

Thomas, K. L. (2007). Material Matters. Architecture and Material Practice. Abingdon: Routledge.

Yau, Y. (2012). Normas, sentido de comunidad y colectivismo comunal en un contexto de edificios en altura. Revista INVI, 27(76), 17-72. 